IZA DP No. 8794

Commuting Time and Household Responsibilities: Evidence Using Propensity Score Matching

J. Ignacio Gimenez-Nadal Jose Alberto Molina

January 2015 


\title{
Commuting Time and Household Responsibilities: Evidence Using Propensity Score Matching
}

\author{
J. Ignacio Gimenez-Nadal \\ University of Zaragoza \\ and CTUR \\ Jose Alberto Molina \\ University of Zaragoza \\ and IZA \\ Discussion Paper No. 8794 \\ January 2015 \\ IZA \\ P.O. Box 7240 \\ 53072 Bonn \\ Germany \\ Phone: +49-228-3894-0 \\ Fax: +49-228-3894-180 \\ E-mail: iza@iza.org
}

Any opinions expressed here are those of the author(s) and not those of IZA. Research published in this series may include views on policy, but the institute itself takes no institutional policy positions. The IZA research network is committed to the IZA Guiding Principles of Research Integrity.

The Institute for the Study of Labor (IZA) in Bonn is a local and virtual international research center and a place of communication between science, politics and business. IZA is an independent nonprofit organization supported by Deutsche Post Foundation. The center is associated with the University of Bonn and offers a stimulating research environment through its international network, workshops and conferences, data service, project support, research visits and doctoral program. IZA engages in (i) original and internationally competitive research in all fields of labor economics, (ii) development of policy concepts, and (iii) dissemination of research results and concepts to the interested public.

IZA Discussion Papers often represent preliminary work and are circulated to encourage discussion. Citation of such a paper should account for its provisional character. A revised version may be available directly from the author. 


\section{ABSTRACT}

\section{Commuting Time and Household Responsibilities: Evidence Using Propensity Score Matching*}

The growth in women's participation in the labor force has attracted attention to the gender differences in commuting behavior, and to their implications. This study analyses the relationship between individual commuting behavior and household responsibilities, with a focus on gender differences in that relationship. Using the Dutch Time Use Surveys for the years 2000 and 2005, we analyze the relationship between commuting time, and the time devoted to home production and childcare. To deal with reverse causality, we use Propenstity Score Matching techniques to obtain imputed data for individuals. After reverse causality is taken into account, we find that the effect of home production on commuting time for women is more than double the effect for men, while childcare time has an effect on women's commuting time behavior only. Our results explain why prior studies have found that women have shorter commutes than men, shedding light on the Household Responsibility Hypothesis (HRH).

JEL Classification: D13, J16, J22

Keywords: commuting, home production, childcare, propensity score matching, Multinational Time Use Study

Corresponding author:

Jose Alberto Molina

Department of Economic Analysis

Faculty of Economics

University of Zaragoza

Gran Vía 2

50005 Zaragoza

Spain

E-mail: jamolina@unizar.es

\footnotetext{
* This paper was partially written while Jose Alberto Molina was Visiting Fellow at the Department of Economics of Boston College (US), to which he would like to express his thanks for the hospitality and facilities provided. This paper has benefited from funding from the Spanish Ministry of Economics (Project ECO2012-34828).
} 


\section{Introduction}

In this paper, we analyze the relationship between commuting time and the time devoted to both home production and childcare, with a focus on gender differences. We use the Dutch Time Use Surveys for the years 2000 and 2005, which allow us to analyze the time devoted to commuting, home production, and childcare during the day, and with information for seven days of the week for each individual. Furthermore, to deal with reverse causality, we use Propensity Score Matching techniques to obtain imputed data for individuals. The fact that individuals report their daily activities, in their own words, makes these surveys extremely helpful, as has been shown in Gimenez-Nadal and Molina (2014), given that individual perceptions determine whether the activity is considered as commuting, or not.

Recent studies have shown that most household responsibilities (e.g., time devoted to home production and childcare) continue to be carried out by women (Aguiar and Hurst, 2007; Gimenez-Nadal and Sevilla, 2012), and evidence from time use surveys in developed countries shows that there is still a gender gap in commuting time favouring men, and that this difference has remained relatively constant over time. More specifically, Figure 1 shows the average time devoted to commuting by men and women in the Netherlands, the United Kingdom, and the United States in recent decades, obtained from an analysis of the Multinational Time Use Study. We observe that the average commuting time of women is well below that of men, and that such gender differences in commuting time have remained relatively constant in the 3 countries, and have even increased in the UK.

Prior literature on the effect of gender on commute duration is not conclusive. Some studies have shown that commuting differences by gender changed little, historically, with women's trip lengths remaining substantially below those of men (see, among others, Kain, 1962; Rosenbloom, 1978; Giuliano, 1979; Wachs, 1987, 1991). Crane (2007) shows that, in the US, after controlling for other sources of difference, such as demographics and community features, the average woman's trip to work differs markedly from the average man's. ${ }^{1}$ Iwata and Tamada (2008) show that time spent by Japanese married women in commuting follows a backward-bending pattern. Sandow and Westin (2010) find that Swedish women have a shorter commute than men

\footnotetext{
${ }^{1}$ Other recent studies about gender differences in commute time are Blumen (1994), Lee and McDonald (2003), and Mok (2007).
} 
regardless of employment sector, education level, and family situation, indicating that the gender role and the daily time constraints of women impose stricter limitations on women's geographical labor mobility. But other studies have challenged the idea that transportation needs of women are different with respect to those of men. Doyle and Taylor (2000) argue that commute times converged for gender, among other variables, as early as the mid-1990s. Gossen and Purvis (2005) report that San Francisco journeyto-work times in 2000 were the same for women and men in all age groups, except for those in their 50s, and Vandersminssen, Thériault and Villenueve (2006) show that commute distances in the Quebec Metropolitan Area also converged when controlling for type of household or for the presence of children.

The debate about gender differences in commuting behaviour is reflected in theories about women's commuting trips. Rational utility theorists argue that women's lesser attachment to the labour force is behind women's shorter commute times, with these gender differences tending to diminish in the near future. Others contend that women's shorter commutes are an outcome of the constraints society puts on women at home and at work, with these being divided into those who attribute the source of the difference to the problem of gender discrimination in the labour market, and those who attribute it to women's household responsibilities, thus hypothesizing that the disproportionate burden of household responsibility on women requires short commute times and makes it difficult for them to work away from home (this has come to be known as the Household Responsibility Hypothesis, HRH).

Considering the HRH issue, Turner and Neimeier (1997) review prior evidence regarding the relationship between commuting and household responsibility, and find that the research evaluating the degree to which this gender differential in commuting can be explained by the division of labour in the household has produced mixed results, despite that the authors find evidence in favour of the HRH. Against this background, this paper focuses on testing the HRH, and offers new empirical findings. To that end, we use the sample of working individuals from the Dutch Time Use Surveys (DTUS) of 2000 and 2005 to empirically address the relationship between commuting time and the time devoted to both home production and childcare activities. One substantial advantage of the DTUS over other time use surveys, such as the American, the Australian, and the British, is that there is time use information for 7 consecutive days for each individual, allowing us to take into account potential variations of commuting 
times across days. In our empirical analysis, we take into account that the time devoted to commuting, home production, and childcare are choices workers make, and we thus propose the use of a matching strategy (Propensity Score Matching) to deal with potential reverse causality between commuting time and household responsibilities.

Our results show that, after reverse causality is taken into account, the effect of home production on commuting time for women is more than double the effect for men, while childcare time affects only women's commuting time. As the negative relationship between commuting time and time devoted to home production is greater for women, we interpret this result as evidence that such responsibilities impose more restrictions on commuting time for women, compared to men, which explains why women have shorter commutes. Moreover, the fact that childcare is negatively associated with women's commuting time also helps to explain why women have shorter commutes than men.

Our contribution to the literature is threefold. First, as argued by Crane (2007), understanding the effect of women's roles on their commute lengths may help predict future housing and work-place location preferences, depending on their household responsibilities and lifestyles, and it can also help predict future location decisions of employers who want to employ women, who may or may not be spatially restricted. Our study proves relevant for this issue. Second, it may be relevant for future transportation planning, regarding the varied demands of transportation modes for women and men. For instance, it could be that, due to their household responsibilities, women may be more likely than men to use public transport (Schulz and Gilbert, 1996; Doyle and Taylor, 2000; Hamilton and Jenkins, 2000; Hoedemaeker et al., 2012; Sánchez de Madariaga, 2013). Third, we introduce time use surveys as an alternative data source to analyze individual commuting behaviour. As has been shown in Gimenez-Nadal and Molina (2014), the use of this type of survey together, with the Propensity Score Matching method, are helpful in analyzing the relationships between labour market hours, commuting time, and other uses of time.

The rest of the paper is organized as follows. Section 2 reviews the factors that have been identified as being related to the commuting behaviour of individuals. Section 3 describes the data. Section 4 describes the empirical strategy, Section 5 describes our results, and Section 6 sets out our main conclusions. 


\section{Factors related to commuting behavior}

Prior research has identified numerous potential influences on commuting habits, and they can basically be grouped in 3 categories: microeconomic, land use/geographical, and macroeconomic factors. The microeconomic and land use/geographical variables are the most common analyzed characteristics, while the analysis of macro variables, such as the use of Gross Domestic Product (GDP) or (lagged) changes in GDP to make predictions, or as a control variable, is quite limited in the literature (Dargay and Gately, 1999; Johansson et al., 2002; Östh and Lindgren, 2012).

Regarding the microeconomic variables, characteristics such as gender, age, level of education, personal income, presence and number of children, home ownership, or car availability/ownership, have all been considered as influencing the commuting behavior of individuals. The factors that may have a positive relationship with commuting are personal income (Benito and Oswald, 2000; Pucher and Renne, 2003; Rouwendal and Nijkamp, 2004; Schwanen et al., 2004; Dargay and Van Ommeren, 2005; Simonsohn, 2006; Susilo and Maat, 2007; Sandow, 2008; Sandow and Westin, 2010; Dargay and Clark, 2012; Gutiérrez-i-Puigarnau and Van Ommeren, 2012; Östh and Lindgren, 2012), education (Benito and Oswald, 2000; Susilo and Maat, 2007; Sandow, 2008; Östh and Lindgren, 2012), and home ownership (Deding et al., 2008; Groot et al., 2012) and car ownership (Pucher and Renne, 2003; Schwanen et al., 2004; Dargay and Clark, 2012). Microeconomic factors that have been found to have a negative relationship with commuting are gender (Hanson and Hanson, 1993; Turner and Niemeier; 1997; Kwan; 1999; Hjorthol; 2000; Simonsohn, 2006; Sandow, 2008; Sandow and Westin, 2010; Dargay and Clark, 2012; Groot et al., 2012; Gutiérrez-i-Puigarnau and Van Ommeren, 2012), age (Susilo and Maat, 2007; Sandow and Westin, 2010; Van Acker and Witlox, 2011; Dargay and Clark, 2012; Östh and Lindgren, 2012) and children (Simonsohn, 2006; Sandow, 2008; Gutiérrez-i-Puigarnau and Van Ommeren, 2012). Other factors that have been included in the analysis of commuting behavior are the full-/part-time status of workers (Benito and Oswald, 2000; Van Acker and Wiltox, 2011; Groot et al., 2012), partner's commute (Sandow and Westin, 2008), and country of origin (Östh and Lindgren, 2012).

For the land use/geographical variables, other studies have found a negative relationship between commuting and population/residential density (Rouwendal and Nijkamp, 2004; Schwanen et al., 2004; Susilo and Maat, 2007; Sandow, 2008; Dargay 
and Clark, 2012) and job density (Johansson et al., 2002; Rouwendal and Nijkamp, 2004). Factors that may condition the commuting behavior of individuals are the urban/rural residence (Schwanen et al. 2004; Susilo and Maat, 2007; Östh and Lindgren, 2012), residential region (Pucher and Renne; 2003; Sandow and Westin, 2010), housing price (Rouwendal and Nijkamp, 2004), and intensity of land use (Rouwendal and Nijkamp, 2004; Van Acker and Wiltox, 2011), among others. ${ }^{2}$

Several explanations can be used to address the gender differences in commuting behavior. First, it could be that differences in the socio-demographic characteristics of men and women explain the gender gap in commuting distance and time, as higher income and education are positively related with commuting distance. However, and despite that the gender difference in commuting decreases when one controls for income and occupation (Singell and Lillydahl, 1986; Gordon et al., 1989; Hanson and Johnston, 1995; Sandow and Westin, 2010), the difference does not disappear. A second factor is geographical, as there are gender-segregated labour markets in which women are concentrated in female-dominated occupations. To the extent that these femaledominated occupations are more evenly distributed, compared to male-dominated occupations, women have greater possibilities to find a job closer to home, with a shorter commute (Hanson and Johnston, 1985; Hanson and Pratt, 1995). The third and main hypothesis of this paper is related to social roles: social roles for men and women are different, and women must adapt their commuting patterns to their chores at home, accepting jobs closer to home (Turner and Niemeir, 1997; Sandow and Westin, 2010). In an analysis using German data, Gutiérrez-i-Puigarnau and Van Ommeren (2010) find that the effect of commuting distance on labour supply patterns is (much) stronger for female workers, which may indicate that female workers are more restricted in their commuting behaviour, consistent with differential social roles. Similarly, Compton and Pollak (2014) find that the predicted probability of employment and labour force participation is higher for married women with young children, living in close proximity to their mothers or their mothers-in-law, compared with those living further away. This is consistent with the Household Responsibility Hypothesis, which posits that women must adapt their employment patterns to their chores at home.

\footnotetext{
2 Despite the fact that household location choice models with commuting distance have been developed (e.g., DeSalvo (1985); DeSalvo and Huq, 2005; Ng, 2005; Deding, Filges and Van Ommeren, 2009), we consider the location choice as fixed.
} 


\section{Data: The Dutch Time Use Surveys, 2000 and 2005}

The data used for the empirical analysis is drawn from the versions of the Dutch Time Use Survey 2000 and 2005 included in the Multinational Time Use Study (MTUS). The DTUS contains information on daily activities, gathered by means of the completion of a personal diary, and household and individual questionnaires. Both surveys were conducted in October of the reference year, and one member of the household, aged 12 or older, was selected to report information on daily activities during 7 consecutive days. The diary time frame is twenty-four consecutive hours (from 12:00 a.m. until 12:00 a.m. the following day) and is divided into fifteen-minute intervals.

The MTUS is an ex-post harmonized cross-time, cross-national, comparative time use database, coordinated by the Centre for Time Use Research at the University of Oxford. It is constructed from national randomly-sampled time-diary studies, with common series of background variables, and total time spent in 41 activities (Gershuny, 2009). The MTUS provides us with information on individual time use, based on diary questionnaires in which individuals report their activities throughout the 24 hours of the day. The advantage of time-use surveys over stylized-questions, such as those included in the data bases ECHP, the BHPS, and the SOEP (where respondents are asked how much time they have spent, for example, in the previous week, or normally spend each week, on market work or home production) is that diary-based estimates of time use are more reliable and accurate than estimates derived from direct questions (Juster and Stafford, 1985; Robinson, 1985; Bianchi et al., 2000; Bonke, 2005; Yee-Kan, 2008).

In the labour supply literature, Klevmarken (2005) argues that information on actual hours of work from time-use surveys is more relevant than the normal hours or contracted hours generally reported in stylized questions. This author shows that timeuse data yields much smaller estimates of wage-rate effects compared to measures of normal hours of work, which may have important implications for tax policy design, among other things. Thus, in the same way that money-expenditure diaries have become the gold standard in the consumption literature, so have time-use diaries become the preferred method of gathering information on time spent on market work, non-market work, and leisure. Most studies documenting how individuals use their time are now based on these data sets, including recent studies of the analysis of trends in time use 
(Aguiar and Hurst, 2007; Guryan, Hurst and Kearney, 2008; Gimenez-Nadal and Sevilla, 2012; Sevilla et al., 2012). ${ }^{3}$

For the sake of comparison with prior studies (Aguiar and Hurst, 2007; GimenezNadal and Sevilla, 2012), we restrict our sample to full-/part-time workers between the ages of 21 and 65 (inclusive). Our results can thus be interpreted as being "per working adult”, who are likely to commute in their working days. Additionally, given that households have typically been defined as those formed by a couple and their children (Connelly and Kimmel, 2009; Gimenez-Nadal and Molina, 2013), we also restrict the sample to individuals who are the head of the household or the spouse/partner of the couple (e.g. we only analyze individuals living in couples). Finally, for the analysis of the relationship between childcare responsibilities and commuting, we additionally restrict the sample to individuals living in couple with at least one child under 18 in the household. The existing literature (Kalenkoski, Ribar and Stratton, 2005; Guryan, Hurst and Kearney, 2008) shows that the time devoted to childcare activities by men and women depends on their family status, with single parents devoting less time to their children.

Our variables of interest refer to the daily time devoted to commuting, home production, and childcare. For the time devoted to Commuting, we use the information collected in the variable main63 "travel to or from work" of the MTUS, measuring the time devoted to Commuting during the reference day. For the time devoted to Home Production, we use the information collected in the variables main18 "food preparation, cooking”, main19 “set table, wash/put away dishes”, main20 “cleaning”, main21 "laundry, ironing, clothing repair”, main22 "home/vehicle maintenance/improvement”, main23 "other domestic work", main24 "purchase goods", main26 "consume other services”, main27 “pet care (other than walk dog)”, main32 “adult care”, main66 "child/adult care-related travel", and main67 "travel for shopping, personal or household care”, and we sum the time devoted to all these activities. For the time devoted to Childcare, we use the information collected in the variables main28 “physical, medical childcare”, main29 “teach, help with homework”, main30 "read to, talk or play with child”, and main31 “supervise, accompany, other childcare”, and we

\footnotetext{
3 The MTUS has been widely used across the social sciences (Gershuny, 2000; Gershuny and Sullivan, 2003; Gauthier et al., 2004; Guryan, Hurst and Kearney, 2008; Gershuny, 2009, Gimenez-Nadal and Sevilla, 2011;2012; Gimenez-Nadal and Molina, 2013).
} 
sum the time devoted to all these activities. Thus, we have information for Commuting, Home Production and Childcare at the individual level for the seven days of the week.

\section{Empirical evidence}

Table 1 shows the overall time devoted to Commuting, Home Production, and Childcare for all the working individuals in our sample, by gender. We observe that men devote 0.90, 1.18 and 0.53 hours per day to Commuting, Home Production and Childcare, while women devote 0.62, 2.65 and 1.06 hours per day to those activities, respectively. ${ }^{4}$ We find a gender difference in the time devoted to Commuting that is statistically significant at standard levels, with male workers devoting more time to this activity (0.28 more hours per day) compared to their female counterparts, consistent with the existing literature showing that men have longer commutes than women (Pazy et al., 1996; Turner and Neimeier, 1997; Plaut, 2006). ${ }^{5}$ We also find a gender gap favouring females in Home Production and Childcare, with women devoting 1.47 and 0.53 more hours per day, respectively, to these activities compared to their male counterparts, with such differences being statistically significant at standard levels. Thus, we find that working females, compared to their male counterparts, devote less time to Commuting and more time to Home Production and Childcare, which is consistent with the HRH framework, within which women have shorter commutes because they have more household responsibilities. Additionally, these differences in the time devoted to the three activities are also reflected in terms of participation in the activity, as the percentage of males doing Commuting on any day is larger compared to females, while the opposite holds for Home Production and Childcare. In this sense, males are 5.67 percentage points more likely to do Commuting during the day of the diary, while they are also 17.34 and 16.29 percentage points less likely to do Home Production and Childcare, respectively. These differences indicate that men not only devote more time to Commuting, but are also more likely to commute, and the opposite holds for Home Production and Childcare.

\footnotetext{
${ }^{4}$ We have used all the individuals in our sample to compute the average time in Commuting and Home Production. In the case of Childcare time, we use individuals with at least one child under 18 in the household.

${ }^{5}$ Diff. Men-Women measures the difference in the overall value of the variable for men and women, $p$-value diff shows the p-value of a t-type test of equality of means. A p-value lower than 0.05 indicates that the difference between the mean values is statistically significant at standard levels.
} 
Figure 2 shows kernel-density distributions for the time devoted to Commuting, Home Production, and Childcare for both men and women. ${ }^{6}$ We observe that the time devoted to Commuting is concentrated between 0 and 2 hours per day for both men and women, and that the variation of Commuting for women is smaller than the variation for men, as the variance coefficient yield values of 0.70 and 0.32 for men and women, respectively. Considering the time devoted to Home Production by men and women, we observe that it is concentrated in less than 4 hours per day for males, and 6 hours per day for females, yielding variance coefficients of 4.42 and 5.87 for men and women, respectively, showing that there is more daily variation in Home Production time for females than for males. For the time devoted to Childcare by men and women who have at least one child under 18, we observe that it is concentrated in less than 2 hours per day, and there is more daily variation in the time devoted to this activity for women, as variance coefficients for men and women are 0.75 and 2.04, respectively. We also note that the time devoted to these three activities does not follow a normal distribution, as the values of skewness and kurtosis are different for reference values of 0 and 3 , respectively.

Figure 3 plots the mean time devoted to Commuting, on the one hand, and the time devoted to Home Production and Childcare, on the other, at the individual level, for both men and women, on working days. Specifically, for a given individual and for the days that the individual reported positive time in market work (days when individuals devote at least 1 hour to market work, excluding commuting), we compute the average time devoted to these activities, obtaining one value for Commuting, Home Production, and Childcare for the reference individual. We then plot (scatterplot) the mean time devoted to Commuting (y-axis) on the time devoted to Home Production or Childcare (x-axis) for all individuals. In the case of men, we observe that, in the range between 0 and 2 hours of Commuting, where most observations are concentrated, the variation is rather small. In the case of women, we observe a larger variation in the distribution, as the points are more evenly distributed over the different times devoted to Home Production and Childcare. Thus, it seems that there is a larger variation for women in the relationship between Commuting, and Home Production and Childcare.

\footnotetext{
${ }^{6}$ The analysis is restricted to working days, defined as days where respondents devote 60 or more minutes to market work activities, excluding commuting, where market work is defined as the sum of the time devoted to the categories main7 "paid work, main job (not at home)", main8 "paid work at home”, main9 "second or other job not at home", main11 "travel as a part of work" and main12 "other time at workplace".
} 
Figure 4 plots the average time devoted to Commuting for each time devoted to Home Production and Childcare; that is, for all the diaries with the same amount of time devoted to Home Production, we average the time devoted to Commuting by gender. The same applies to Childcare time. We plot mean Commuting time (y-axis) on the time devoted to Home Production or Childcare (x-axis). We have also added a linear prediction of Commuting time on Home Production or Childcare, including confidence intervals at the 95 per cent level. As can be seen, the linear predictions are a good fit for both men and women, as many values of Commuting are in the confidence intervals of the linear prediction. Additionally, the linear prediction yields a negative slope for the relationship between Commuting, and Home Production and Childcare, indicating that there is a negative raw correlation between Commuting and the other two non-market work activities. Raw partial correlations show that the correlation between Commuting and Home Production is -0.30 and -0.32 for men and women, while the correlation between Commuting and Childcare is -0.10 and -0.13 for men and women, respectively.

\section{Empirical Strategy}

We estimate Tobit (Tobin, 1958) models on the time devoted to Commuting, by gender. Foster and Kalenkoski (2013) compare the use of Tobit and OLS models in the analysis of the time devoted to childcare activities, finding that the qualitative conclusions are similar for the two estimation methods. We have also estimated OLS models, and results (available upon request) are qualitatively the same.

The statistical model is as follows. For a given individual 'i', let $C_{i j}$ represent the daily hours individual " $\mathrm{i}$ " on day “ $\mathrm{j}$ ” devotes to commuting, let Home_Production $_{i j} /$ Childcare $_{i j}$ be the time devoted to home production/childcare by individual "i" in day “j”, let $X_{i}$ be a vector of socio-demographic and regional characteristics, and let $\varepsilon_{i j}$ be random variables that represent unmeasured factors. We suppose that there is a latent variable $\left(C^{*}{ }_{i j}\right)$ that linearly depends on $X_{i}$ via the parameters $\beta$ and (vector) $\gamma$ that determines the relationship between Home_Production $_{i j} /$ Childcare $_{i j}$ and the independent vector $X_{i}$, on the one hand, and $C_{i j}^{*}$, on the other. The observable variable $\left(C_{i j}\right)$ is defined as being equal to the latent variable whenever the latent variable is above zero, and ' 0 ' otherwise. We estimate the following equations: 


$$
\begin{gathered}
C_{i j}=\left\{\begin{array}{l}
C_{\mathrm{ij}}^{*} \text { if } \mathrm{C}_{\mathrm{ij}}^{*}>0 \\
0 \text { if } \mathrm{C}_{i j}^{*} \leq 0
\end{array} \text { where } \mathrm{C}_{\mathrm{ij}}^{*}=\alpha+\beta_{1} \text { Home_Production }_{i j}+\gamma X_{i}+\varepsilon_{i j}\right. \\
C_{i j}=\left\{\begin{array}{l}
C_{\mathrm{ij}}^{*} \text { if } \mathrm{C}_{\mathrm{ij}}^{*}>0 \\
0 \text { if } \mathrm{C}_{i j}^{*} \leq 0
\end{array} \text { where } \mathrm{C}_{\mathrm{ij}}^{*}=\alpha+\beta_{2} \text { Child_Care }{ }_{i j}+\gamma X_{i}+\varepsilon_{i j}\right.
\end{gathered}
$$

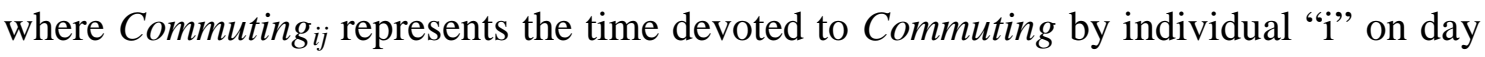
“j” $(\mathrm{j}=1,3 . . .7)$, and Home_Production ${ }_{i j}$ and Child_care ${ }_{i j}$ is the time devoted to Home Production and Childcare by individual “i” on day “j”. Where the raw data shows a negative relationship between Commuting, and Home Production and Childcare (see Figure 4), we would expect to find that $\beta_{1}<0$ and $\beta_{2}<0$. Given prior research showing that the factors affecting time-allocation decisions of men and women are different (Gimenez-Nadal and Sevilla, 2011;2012; Gimenez-Nadal and Molina, 2013), we run each model separately by gender. As the distributions of Commuting, Home Production and Childcare do not follow a normal distribution, we have corrected the standard errors, and we have additionally clustered the observations at the individual level in order to account for the unobserved heterogeneity of individuals.

The vector $X_{i}$ includes socio-demographic and regional characteristics, according to the factors reviewed in Section $2{ }^{7}$ We include age and its square, university education, secondary education, working full-time (as opposed to part-time), whether the partner is employed (a proxy for the commuting probability of the partner), the number of children under 18 in the household, whether the youngest child in the household is under 5 , between $5-12$, or between $13-17$, if there is at least one motorized vehicle at home (as an indicator of car availability), and whether there is at least one computer at home, to control for the possibility that the respondent may be doing tele-work. We also include a vector of dummy variables to scale the day of the week (Ref.: Saturday), and we cluster observations by individuals to take into account potential variations of commuting times across days.

Existing research has shown a relationship between wages and individual commuting behaviour (Van Ommeren et al, 2000; Rupert et al., 2009), but unfortunately the DTUS does not include wages or earnings of individuals. However, to the extent that income and education have been found to have a positive relationship with commuting time, we use education and household income as proxies for earnings. This household income

\footnotetext{
${ }^{7}$ Table 1 shows summary statistics for all the socio-demographic and land use/geographical variables.
} 
refers to monthly household income in $€$. Moreover, prior research has shown a relationship between occupation and commuting (Hanson and Johnston, 1985; Gordon et al., 1989; Hanson and Pratt, 1995), as female-dominated occupations are more evenly distributed compared to men, and thus women may choose jobs closer to home. One of the limitations of the DTUS is that it does not contain information on occupations, despite that we can control for whether the individual works in the public sector or not, since the category of female-dominated occupations includes jobs in the public sector (Sandow and Westin, 2010). Thus, we cannot identify the relationship between commuting time and non-market work (home production and childcare) net of individual heterogeneity in occupations. We expect that this heterogeneity in occupations may induce an upward bias in the relationship between gender, commuting, and non-market work, as one channel that may explain gender differentials in commuting behaviour is a gender-segregated labor market - despite the fact that Sandow and Westin (2010) find that women consistently have shorter commutes than men employed in the same sector.

Finally, we include a set of variables that may be considered relevant from the point of view of land use/geographical factors, and considering the aggregation level that we are able to obtain with the two datasets. The first refers to the urban/rural residence of individuals, as we do have information on whether individuals live in an urban or rural area. This variable is originally coded by the MTUS team and thus we cannot vary the definition of urban/rural residence. Additionally, there is information on the region of residence of the respondent, coded according to the 12 major regions in the Netherlands (Drenthe, Flevoland, Friesland, Gelderland en Zop, Groningen, Limburg, Noord Brabant, Noord Holland, Overijssel en Nop, Utrecht, Zeeland and South Holland) plus an additional variable including respondents in Amsterdam, Rotterdam and The Hague. With this information, we include dummy variables to control for the regional residence of respondents, with South Holland being the reference category. We have included the population density and housing prices defined for these regions. To compute the population density, we obtained figures from Eurostat for each of the 12 regions in both 2000 and 2005, and for the category with the 3 cities we have considered the population density for Amsterdam. In the case of housing prices, for each region, we have used the House Price Index of all dwellings with base 2005, obtained from the Statistics 
Netherlands, and where for the category with the 3 cities we have considered the House Price Index in Amsterdam.

\section{Propensity Score Matching}

We must beware of endogeneity in our analysis, since commuting distance, commuting time, and non-market work activities could all be related to unobserved factors that influence the individual choices of where to live, where to work, and how to get from one to the other. Thus, to estimate the empirical relationship between commuting and non-market work hours, we must deal with potential endogeneity between commuting and the time devoted to home production or childcare. As a method to overcome this problem, we propose the use of Propensity Score Matching to impute the time devoted to Home Production and Childcare. Our strategy is based on Borra, Sevilla and Gershunny (2013), and applied in Gimenez-Nadal and Molina (2014) where the authors use a statistical matching method to combine data from two different datasets to obtain imputed values of a range of uses of time.

The PSM method was originally proposed by Rosenbaum and Rubin (1983) to evaluate employment and education programs (Lalonde, 1986; Fraker and Maynard, 1987; Dehejia and Wahba, 2002), and it is suitable when an experimental design is not feasible, or when the evaluation questions are broader than assessing the effect of an intervention on participants, and it allows us to match individuals in a treatment group to others who did not participate, but have comparable characteristics.

The innovation of PSM compared to other matching methods is that it develops a single (propensity) score that encapsulates multiple characteristics, rather than requiring a one-to-one match of each characteristic, simplifying matching by reducing dimensionality. The interest in PSM accelerated after Heckman et al. (1998a,b) assessed the validity of using propensity matching to characterize selection bias using experimental data. PSM employs a predicted probability of group membership (treatment vs. control group), based on observed predictors usually obtained from a logistic regression to create a counterfactual group.

One of the advantages of these matching methods over regression is that the variation in the imputed variable that occurs in the donor dataset is simulated as closely as possible, given that a unique donor value can be found for each recipient record 
(Connelly and Kimmel, 2009). Another benefit is that it restricts inferences to samples for which there is overlap in covariate distributions across data sets (the common support region), thereby avoiding unwarranted model extrapolations (Dehejia and Wahba, 2002). A further advantage of matching over regression analysis is that it is non-parametric: matching does not impose functional form restrictions, such as linearity and homogeneous effects on the distribution of covariates, both assumptions being usually unjustified, either by the economic theory or by the data (Zhao, 2008). Moreover, matching does not require exclusion restrictions for the identification of the imputed variable when used in the combined dataset.

To implement propensity score matching, both datasets are combined and a dummy variable is constructed taking value 1 if the observation belongs to the recipient file DTUS 2005, and value 0 if the observation belongs to the donor file DTUS 2000. The propensity score is defined as the probability of belonging to the recipient database, conditional on the common observed covariates $\left(\mathrm{p}\left(\mathrm{X}_{\mathrm{i}}\right)=\operatorname{Pr}(i \in\right.$ DTUS 2005 $\left.X=x)\right)$. Hence, we consider individuals included in the 2005 survey as if they are the treated group, and individuals included in the 2000 survey as if they are the untreated group. Thus, individuals from 2000 are used to impute the time devoted to non-market work (home production and childcare) by individuals in 2005, and individuals from 2005 are used to impute the time devoted to non-market work by individuals in 2000. This imputed non-market work time can still be used to examine the relationship between commuting time and non-market work hours, since the imputed variable preserves the variation of the original data. Additionally, given that the same factors may differentially affect the time devoted to both home-production and child-care, depending on the gender of the respondents, we apply this matching strategy by gender.

We first specify and estimate a binomial probit model of the probability of belonging to the 2005 sample; that is, we obtain the propensity score. Second, we impose the common support condition; that is, we restrict the 2000 sample to observations whose estimated propensity scores lie within the ranges of estimated propensity scores of the 2005 sample (we lose one male observation from the 2000 sample). Third, we pair each recipient unit with that donor for which the difference between the propensity score is lower in absolute values, and impute the time devoted to Home Production and Childcare for that individual. In this last step, we consider 2005 as recipients and 2000 as donors, and also 2000 as recipients and 2005 as donors, so that individuals in both 
2000 and 2005 have imputed values of individuals from the other survey. During this matching process, each diary is considered as an independent observation, since for each individual we treat each of the 7 diary days as if they were independent observations.

Table 2 shows the results from the probit model of the likelihood of belonging to the 2005 sample, for men and women separately. We run a probit regression of the binary indicator, taking value " 1 ” for observations in the 2005 sample and “ 0 ” for observations in the 2000 sample, over the set of common variables. We consider the demographic and personal characteristics of the respondents (education), household characteristics (living in urban area, computer at home), and time-use behaviour (time devoted to personal care and market work, diary was collected during a working day). In the estimation of the propensity score, the balancing property is fulfilled (the mean propensity score is not different for treated and untreated individuals in each block). ${ }^{8}$ Figures 5A and 5B show the propensity score histograms for both datasets, and for men and women, respectively, showing a high degree of overlap between the two distributions, indicating that the common support assumption is satisfied.

\section{Results}

Columns (1) and (2) in Table 3 show the results of estimating Equation (1) on the time devoted to Commuting, and Columns (3) and (4) show the results of estimating Equation (2) on the time devoted to Commuting. According to results using the original time use variables, we find that both Home Production and Childcare are negatively related to the time devoted to Commuting, consistent with results obtained from Figure 3. Thus, we find that one hour of Home Production per day is associated with 0.26 and 0.27 fewer hours of Commuting per day for both men and women, respectively, while one hour of Childcare per day is associated with 0.35 and 0.37 fewer hours of Commuting per day. These results imply that as the time devoted to non-market work activities increases, the time devoted to commuting decreases, consistent with the

\footnotetext{
${ }^{8}$ In the literature of evaluation of public policies/programs, researchers must face the dimensionality problem, which consists of the lack of common support between the treated and untreated groups with cells containing treated observations and/or untreated observations only, and it is present when the number of covariates is large, or many of the covariates have many values, or are continuous. In this framework, the "Balancing Property" establishes that the mean propensity score must not be different for treated and untreated individuals in each cell, and if this property is not fulfilled, a less parsimonious specification of the propensity score is needed. The fulfilment of this property prevents us from choosing all the covariates used as controls in our main regressions, and only a limited set of such covariates can be included as covariates in the PSM.
} 
Household Responsibilities Hypothesis that considers that household responsibilities decrease the time devoted to commuting. To the extent that females devote 1.47 and 0.53 more hours per day to these activities, we obtain that women devote 0.59 $(1.47 * 0.266+0.371 * 0.53)$ fewer hours per day to commuting time.

However, results for Equations (1) and (2) may be biased, as the time devoted to Commuting, Home Production, and Childcare are jointly determined, and thus our results may suffer from potential endogeneity between commuting time and non-market work activities. Columns (5) to (8) in Table 3 show the results of estimating Equations (1) and (2) on the time devoted to Commuting, where the time devoted to Home Production and Childcare have been imputed using Propensity Score Matching to take into account reverse causality issues. These results can be interpreted as being free of the problem of reverse causality, despite that we cannot identify the relationship between commuting time and labour market hours net of individual unobserved heterogeneity.

Columns (5) and (6) show a negative relationship between Commuting and Home Production for both men and women, with both coefficients being statistically significant at standard levels. In this sense, we find that one hour of Home Production is associated with a decrease of 0.06 hours per day of Commuting for men, while for women it is associated with a decrease of 0.16 hours of Commuting per day. Thus, we find that the negative relationship between commuting time and time devoted to home production is more significant for women, by a factor close to three. A t-type test of equality of the coefficients indicates that the coefficients differ from each other $(p<.01)$, indicating that the effect of Home Production on Commuting is greater for women than for men. Considering the Household Responsibilities Hypothesis, we interpret this result as that these responsibilities impose more restrictions on commuting time for women than for men, which would explain why women have shorter commutes.

Furthermore, if we look at the relationship between Commuting and Childcare, we find that only the Childcare of women has a negative and statistically significant relationship with the time devoted to Commuting, as one hour of Childcare for women is related to a decrease of 0.148 hours in the commuting time of women. In the case of men, we find no statistically significant relationship between Commuting and Childcare. When we control for reverse causality of commuting on childcare, we find that only childcare by women reduces their commuting time, while we find no effect for 
men. This result is consistent with the Household Responsibility Hypothesis, which posits that childcare responsibilities are negatively associated with the time devoted to commuting for women, and also helps to explain why women have shorter commutes.

It is a truism that there are social roles in society, and those roles vary by gender, with our results in this work providing a specific example: women adapt their commuting patterns to their chores (home production and childcare), leading them to take jobs closer to home and thus reducing their commuting time and distance (Turner and Niemeir, 1997; Sandow and Westin, 2010).

Regarding the rest of the socio-demographic and geographic/land use factors, we find that age has an inverted u-shaped relationship with daily commuting for women, with the maximum reached around the age of 40 , and that working full-time, and housing prices, are both positively related to the duration of women's daily commuting.

\section{Conclusions}

The existing literature has shown that commuting entails monetary and mental/physical health costs, and many urban and job search models have included commuting as one of their variables of interest, although the evidence of gender differentials in commuting behaviour has been inconclusive. In this paper, we analyze time use data from three developed countries to determine whether there are gender-variant differences in commuting durations, and whether any such differences have held relatively constant over time. One theory proposed to explain shorter commutes by women is the Household Responsibilities Hypothesis, which posits that the disproportionate burden of household responsibility on women necessitates shorter commuting times and makes it more difficult for them to work away from home.

In this paper, we analyze the relationship between commuting time and the time devoted to both home production and childcare, with a focus on gender differentials. In doing so, we use a sample of working individuals from the Dutch Time Use Surveys (DTUS) of 2000 and 2005 to empirically address the relationship between commuting time and the time devoted to both home production and childcare activities. In our empirical analysis, we take into account that the time devoted to commuting, home production, and childcare are choices workers make, and we thus propose the use of a matching strategy (Propensity Score Matching) to deal with potential reverse causality 
between commuting time and household responsibilities. Our results show that the effect of home production on commuting time for women is more than double the effect for men, while childcare time affects women's commuting time behaviour only; this is consistent with the Household Responsibility Hypothesis.

We hope that our results will stimulate further research on the topic of commuting behaviour and its connection to household responsibilities. Theoretical - as well as further empirical - research is needed to shed light on the question of how gender affects the commuting behaviour of individuals. Furthermore, employment policies should consider the relationship between commuting and household responsibilities, as more family-friendly policies would increase the desire of women to work further away from home, which could ultimately increase their labour force participation.

The data used in this paper impose two limitations. First, it is a cross-section of individuals, which does not allow us to identify the relationship between commuting and household production hours net of (permanent) individual heterogeneity in preferences. Second, our data does not include information on wages or occupations, and so we cannot ascertain the relationship between commuting and household production hours, net of individual heterogeneity, in wages and occupations (factors that have been shown to affect individual commuting behaviour and the gender gap). Alternative datasets with a panel data structure, such as the British Household Panel Survey and the Panel Study of Income Dynamics, both of which provide information on market-work hours, and which lend themselves to a similar matching strategy, could be used to investigate this topic. We leave this issue for future research.

\section{REFERENCES}

Aguiar, M. and E. Hurst (2007). "Measuring trends in leisure: The allocation of time over five decades," Quarterly Journal of Economics 122: 969-1007.

Benito, A. and A.J. Oswald (2000). Commuting in Great Britain in the 1990s. University of Warwick. Department of Economics.

Bianchi, S., M. Milkie. L. Sayer and J.P. Robinson (2000). "Is anyone doing the housework? Trends in the gender division of household labour," Social Forces 79: 191-228.

Blumen, O. (1994). “Gender differences in the journey to work,” Urban Geography 15: 223-245. 
Bonke, J. (2005). "Paid work and unpaid work: Diary information versus questionnaire information,” Social Indicators Research 70: 349-368.

Borra, C., A. Sevilla and J.I. Gershuny (2013). "Calibrating Time Use Estimates for the British Household Panel Survey,” Social Indicators Research 114: 1211-1224.

Compton, J., and R.A. Pollak (2014). “Family proximity, childcare, and women’s labor force attachment,” Journal of Urban Economics 79: 72-90.

Connelly, R., and J. Kimmel (2009). “Spousal influences on parents' non-market time choices," Review of Economics of the Household 7: 361-394.

Crane, R. (2007) “Is there a quiet revolution in women's travel? Revisiting the gap in commuting,” Journal of the American Planning Association 73: 298-316.

Dargay, J.M. and S. Clark (2012). “The determinants of long distance travel in Great Britain.” Transportation Research Part A: Policy and Practice 46: 576-587.

Dargay, J.M., and D. Gately (1997). “The demand for transportation fuels: Imperfect price-reversibility?, Transportation Research Part B: Methodological 31:71-82.

Dargay, J.M., and J. Van Ommeren (2005). "The effect of income on commuting time using panel data.” In 45th Conference of the European Regional Science Association at the Vrije Universiteit Amsterdam, Amsterdam.

Deding, M., Filges, T., and Van Ommeren, J. (2008). “Spatial mobility and commuting: The case of two-earner households,” Journal of Regional Science 49: 113-147.

Dehejia, R.H., and S. Wahba (2002). "Propensity Score-Matching Methods for Nonexperimental Causal Studies,” Review of Economics and Statistics 84: 151-161.

DeSalvo, J.S. (1985). “A Model of Urban Household Behavior with Leisure Choice,” Journal of Regional Science 25: 159-174.

DeSalvo, J.S., and M. Huq (2005). "Mode Choice, Commuting Cost, and Urban Household Behavior,” Journal of Regional Science 45: 493-517.

Doyle, D., and B. Taylor (2000). "Variation in metropolitan travel behaviour by sex and ethnicity," in Travel patterns of people of color: Final report (pp. 181-244), prepared by Battelle, Columbus, Ohio. Washington, DC: U.S. Department of Transportation, Federal Highway Administration.

Foster, G., and C. Kalenkoski (2013). “Tobit or OLS? An empirical evaluation under different diary window lengths,” Applied Economics 45: 2994-3010.

Fraker, T., and R. Maynard (1987). "The Adequacy of Comparison Group Designs for Evaluations of Employment-Related Programs,” Journal of Human Resources 22: 194-227. 
Gauthier, A., T.M. Smmeding, and F.F.J. Furstenberg (2004). "Are parents investing less in children? Trends in selected industrialized countries," Population and Development Review 3: 647-671.

Gershuny, J. (2000). Changing times, work and leisure in post industrial society. Oxford: Oxford University Press.

Gershuny, J.I. (2009). "Veblen in reverse: evidence from the multinational time-use archive," Social Indicators Research 93: 37-45.

Gershuny, J., and O. Sullivan (2003). “Time use, gender, and public policy regimes,” Social Politics: International Studies in Gender, State and Society 10: 205-228.

Gimenez-Nadal, J.I., and J.A. Molina (2013). “Parents’ Education as a Determinant of Educational Childcare Time,” Journal of Population Economics 26: 719-749.

Giménez-Nadal, J.I., and J.A. Molina (2014). “Commuting Time and Labor Supply in the Netherlands: A Time Use Study”, Journal of Transport Economics and Policy 48: 409-426.

Gimenez-Nadal, J.I., and A. Sevilla (2011). “The Time-Crunch Paradox,” Social Indicators Research 102: 181-196.

Gimenez-Nadal, J.I., and A. Sevilla (2012). "Trends in time allocation: a cross-country analysis,” European Economic Review 56: 1338-1359

Giuliano, G. (1979). "Public transportation and the travel needs of women," Traffic Quarterly 33: 607-616.

Gordon, P., A. Kumar and H. Richardson (1989). "Gender differences in metropolitan travel behaviour,” Regional Studies 23: 499-510.

Gossen, R. and Purvis, C. (2005) “Activities, time, and travel: Changes in women’s travel time expenditures, 1990-2000," in Research of Women's Issues in Transportation, Vol. 2: Technical Papers, Transportation Research Board Conference Proceedings 35. Washington, DC: National Research Council.

Groot, S.P., H.L. de Groot and P. Veneri (2012). “The Educational Bias in Commuting Patterns: Micro- Evidence for the Netherlands,” Tinbergen Institute No. 12-080/3

Guryan, J., E. Hurst, and M. Kearney (2008). "Parental education and parental time with children,” Journal of Economic Perspectives 22: 23-46.

Gutiérrez-i-Puigarnau, E., and J.N. van Ommeren (2012). "Labor supply and commuting,” Journal of Urban Economics 68: 82-89. 
Gutiérrez-i-Puigarnau, E., J.N. van Ommeren (2012). "Do rich households live further away from their workplace?” Unpublished manuscript, Free University, Amsterdam.

Hamilton, K., and L. Jenkins (2000). “A Gender Audit for Public Transport: A New Policy Tool in the Tackling of Social Exclusion,” Urban Studies 37: 1793-1800.

Hanson, S., and P. Hanson. (1993). The geography of everyday life. In Gärling and Golledge (Eds), Behaviour and Environment: Psychological and geographical approaches, Amsterdam: Elsevier

Hanson, S. and I. Johnston (1985). “Gender differences in work trip lengths: Implications and explanations,” Urban Geography 6: 193-219.

Hanson, S. and G. Pratt (1995). Gender work and space. International Studies of Women and Place. London: Routledge.

Heckman, J., H. Ichimura and P. Todd (1998a). "Matching as an Econometric Evaluation Estimator,” Review of Economic Studies 65: 261-294.

Heckman, J., H. Ichimura, J. Smith and P. Todd (1998b). “Characterizing Selection Bias Using Experimental Data,” Econometrica 66: 1017-1099.

Hjorthol, R. (2000). "Same city-different options. An analysis of the work trips of married couples in the metropolitan area of Oslo,” Journal of Transport Geography 8: 213-220.

Hoedemaeker, M., M. Parik, B. Baldi, Y. Qiao, C. Sahr and F. Nuñez-Fernández (2012). GOAL: Growing Older, staying mobile: Transport needs for an ageing society, final report.

Iwata, S. and Tamada, K. (2008). “The backward-bending commute times of married women under household responsibility,” CIRJE WP 2008-F-582.

Johansson, B., J. Klaesson, and M. Olsson (2002). “Time distances and labor market integration,” Papers in Regional Science 81: 305-327.

Juster, T., and F.P. Stafford (1985). Time, Goods, and Well-Being. Ann Arbor, MI: Institute for Social Research.

Kain, J.F. (1962) “The journey-to-work as a determinant of residential location,” Papers and Proceedings of the Regional Science Association 9: 137-160.

Kalenkoski. C., D. Ribar and L. Stratton (2005). "Parental childcare in single parent, cohabiting, and married couple families: time-diary evidence from the United Kingdom,” American Economic Review 95: 194-198. 
Klevmarken, N.A. (2005). "Estimates of a labour supply function using alternative measures of hours of work,” European Economic Review 49: 55-73.

Kwan, M. (1999). "Gender, the home-work link, and space-time patterns of nonemployment activities,” Economic Geography 75: 370-394

LaLonde, R. (1986). “Evaluating the Econometric Evaluations of Training Programs with Experimental Data,” American Economic Review 76: 4, 604-620.

Lee, B.S. and McDonald, J.F. (2003) "Determinants of commuting time and distance for Seoul residents: the impact of family status on the commuting of women," Urban Studies 40: 1283-1302.

Mok, D. (2007) "Do two-earner household base their choice of residential location on both incomes?” Urban Studies 44: 723-750.

Ng, C.F. (2008). "Commuting distances in a household location choice model with amenities,” Journal of Urban Economics 63: 116-129.

Östh, J., and U. Lindgren (2012). "Do Changes In Gdp Influence Commuting Distances? A Study Of Swedish Commuting Patterns Between 1990 and 2006.” Tijdschrift voor economische en sociale geografie 103: 443-456.

Pazy, A., I. Salomon, and T. Pintzov (1996). “The impacts of women's careers on their commuting behaviour: a case study of Israeli computer professionals," Transportation Research Part A: Policy and Practice 30: 269-286.

Plaut, P.O. (2006). "The intra-household choices regarding commuting and housing," Transportation Research Part A: Policy and Practice 40: 561-571.

Pucher, J., and J.L. Renne (2003). "Socioeconomics of urban travel: evidence from the 2001 NHTS.” Transportation Quarterly 57: 49-77.

Robinson, J.P. (1985). “The validity and reliability of diaries versus alternative time use measures," in Time, goods, and well-being: Juster and Stafford (eds). Ann Arbor, MI: The University of Michigan, pp 33-62.

Rosenbaum, P.R., and D.B. Rubin (1983). “The Central Role of the Propensity Score in Observational Studies for Causal Effects,” Biometrika 70: 41-55

Rosenbloom, S. (1978). “The need for study of women's travel issues,” Transportation 7: 347-350.

Rouwendal, J. And P. Nijkamp (2004). "Living in Two Worlds: A Review of Home-to-Work Decisions," Growth and Change 35: 287-303 
Rupert, P. E. Stancanelli and E. Wasmer (2009). “Commuting, Wages and Bargaining Power,” Annales d'Economie et de Statistique 95-96: 201-220.

Sánchez de Madariaga, I. (2013). The Mobility of Care: A new Concept in Urban Transportation. In Sánchez de Madariaga and Roberts (Eds.), Fair Share Cities: The Impact of Gender Planning in Europe. London: Ashgate.

Sandow, E. (2008). "Commuting behaviour in sparsely populated areas: evidence from northern Sweden,” Journal of Transport Geography 16: 14-27.

Sandow, E., and K. Westin (2010). "Preferences for commuting in sparsely populated areas: The case of Sweden,” Journal of Transport and Land Use 2: 87-107.

Schulz, D., and S. Gilbert (1996). "Women and Transit Security: A New Look at an Old Issue,” Proceedings of the Women's Travel Issues Second National Conference, October 25-27, Baltimore.

Schwanen, T., F.M. Dieleman and M. Dijst (2004). "The impact of metropolitan structure on commute behavior in the Netherlands: a multilevel approach,” Growth and Change 35: 304-333

Sevilla, A., J.I. Gimenez-Nadal, and J.I. Gershuny (2012). "Leisure inequality in the United States: 1965-2003,” Demography 49: 939-964.

Simonsohn, U. (2006). "New Yorkers commute more everywhere: contrast effects in the field," Review of Economics and Statistics 88: 1-9.

Singell, L., and J. Lillydahl (1986). "An empirical analysis of the commute to work patterns of males and females in two-earner households," Urban Studies 2: 119-129.

Susilo, Y.O., and K. Maat (2007). "The influence of built environment to the trends in commuting journeys in the Netherlands,” Transportation 34: 589-609.

Tobin, J. (1958). "Estimation of relationships for limited dependent variables," Econometrica 26: 24-36.

Turner, T. and Neimeier, D. (1997) “Travel to work and household responsibility: new evidence,” Transportation 24: 397-419.

Van Ommeren, J., G.J. van den Berg and C. Gorter (2000). "Estimating the marginal willingness to pay for commuting,” Journal of Regional Science 40: 541-563.

Vandersmissen, M., Thériault, M. and Villenueve, P. (2006) Work trips: Are there still gender differences? The case of the Quebec metropolitan area. Paper at the Transportation Research Board annual conference, Washington, D.C.

Van Acker, V., and F. Witlox (2011). "Commuting trips within tours: how is commuting related to land use?” Transportation 38: 465-486 
Wachs, M. (1987). "Men, women and wheels: The historical basis of sex differences in travel patterns,” Transportation Reseach Record 1135: 10-16.

Wachs, M. (1991) “Men, women and urban travel: the persistence of separate spheres”. in The car and the city: The automobile, the built environment, and daily urban life, M. Wachs and M. Crawford (eds.), Ann Arbor, MI: University of Michichan Press.

Yee-Kan, M. (2008). “Measuring Housework Participation: The Gap Between "Stylised” Questionnaire Estimates and Diary-Based Estimates,” Social Indicators Research 86: 381-400.

Zhao, Z. (2008). "Sensitivity of propensity score methods to the specifications," Economics Letters 98: 309-319. 
Figure 1. Time devoted to commuting time in the Netherlands, the United Kingdom and the United States, by gender
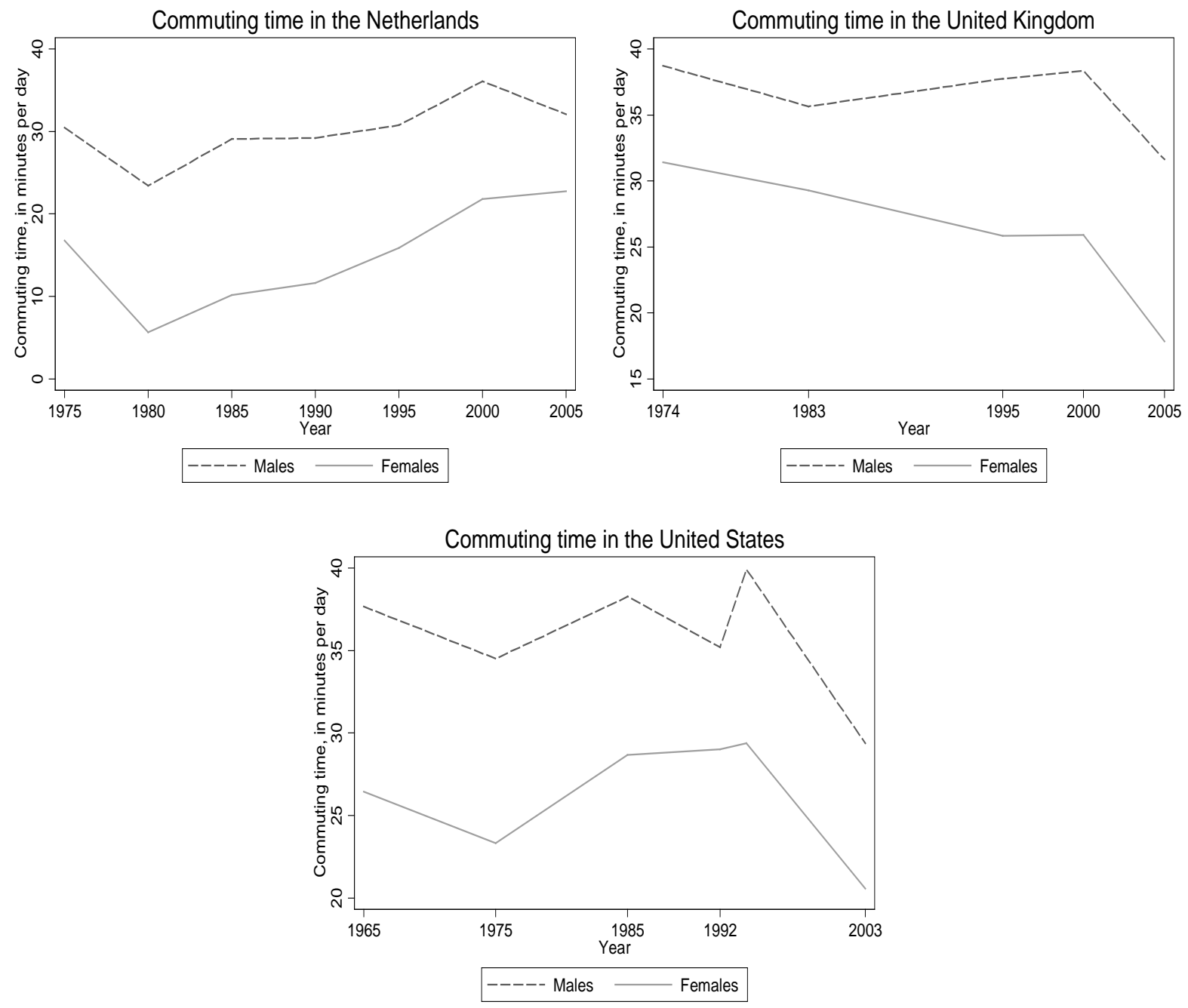

Notes: Source is the Multinational Time Use Study, version W58, accessed in November 2012. Sample consists of male and female respondents who participate in the labour market, from the Netherlands (1975, 1980, 1985, 1990, 1995, 2000, and 2005), the United Kingdom (1974, 1983, 1995, 2000 and 2005) and the United States (1965, 1975, 1985, 1992, 1994 and 2003). Commuting is the time devoted to "travel to or from work". We calculate the average time devoted to commuting by country, survey, and gender, and demographic weights included in the survey are used 
Figure 2. K-density functions for commuting time, home production, and childcare
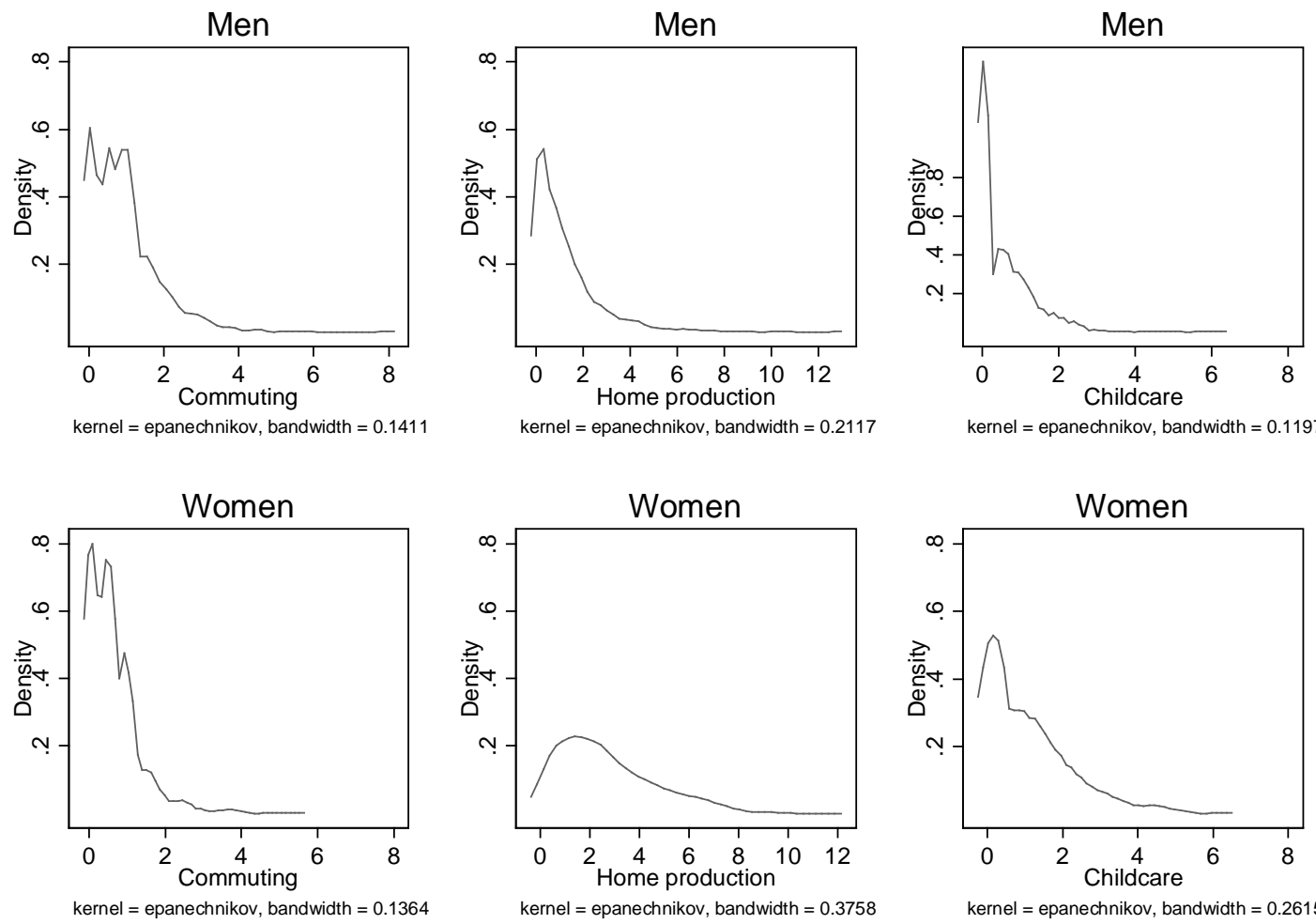

Notes: Sample consists of married male and female respondents aged 21-65, who are the head of the household or the spouse/partner of the household head, from the Dutch Time Use Survey, 2000 and 2005. Commuting is the time devoted to "travel to or from work". Home production includes the time devoted to "food preparation, cooking”, "set table, wash/put away dishes", "cleaning”, "laundry, ironing, clothing repair", "home/vehicle maintenance/improvement", "other domestic work", "purchase goods", "consume other services", "pet care (other than walk dog)", "adult care”, "child/adult care-related travel” and "”travel for shopping, personal or household care". Childcare includes the time devoted to "physical, medical childcare", "teach, help with homework", "read to, talk or play with child" and "supervise, accompany, other childcare". Time use activities are measured in hours per day. The analysis is restricted to working days, defined as days where respondents devote $60+$ minutes to market work activities excluding commuting, where market work is defined as the sum of the time devoted to the categories main7 "paid work, main job (not at home)", main8 "paid work at home", main9 "second or other job not at home", main11 "travel as a part of work" and main12 "other time at workplace". 
Figure 3. Mean time devoted by individuals to commuting, home production, and childcare
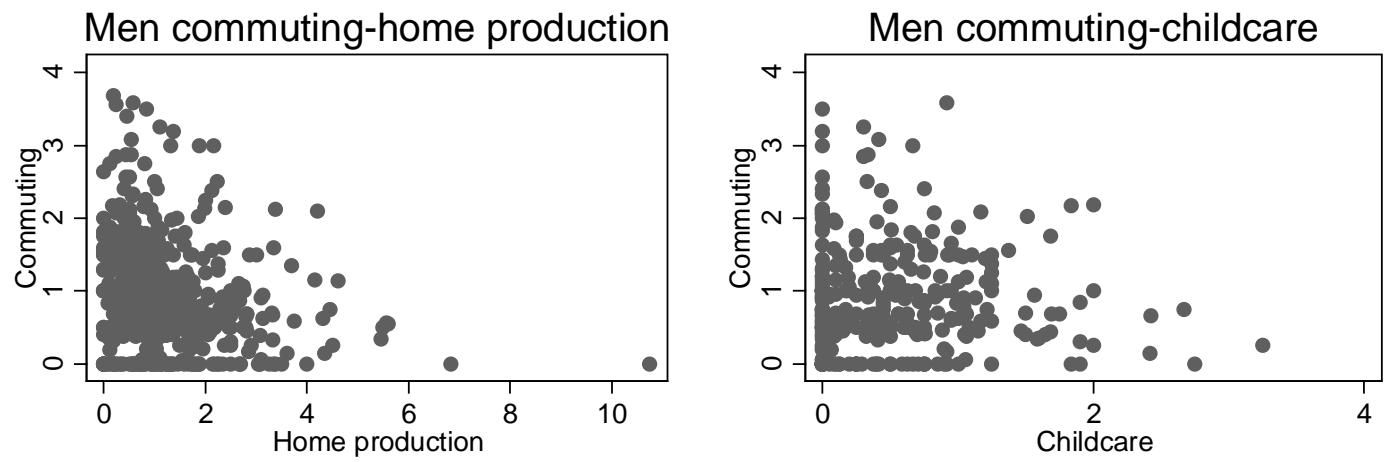

Women commuting-home production
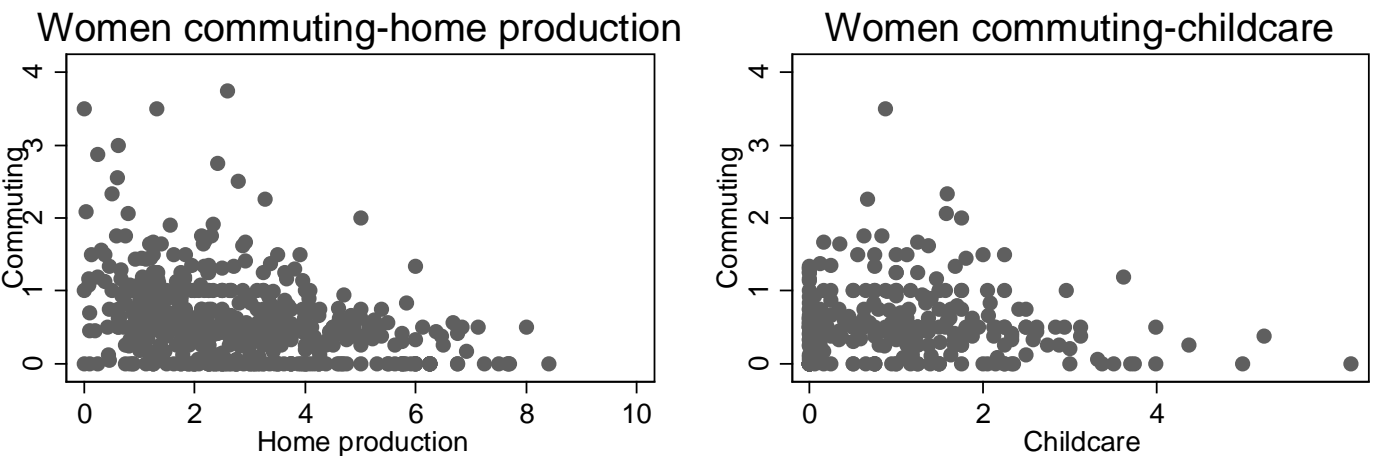

Notes: Sample consists of married male and female respondents aged 21-65, who are the head of the household or the spouse/partner of the household head, from the Dutch Time Use Survey, 2000 and 2005. Commuting is the time devoted to "travel to or from work". Home production includes the time devoted to "food preparation, cooking”, "set table, wash/put away dishes", "cleaning”, "laundry, ironing, clothing repair", "home/vehicle maintenance/improvement", "other domestic work", "purchase goods", "consume other services", "pet care (other than walk dog)", “adult care”, "child/adult care-related travel” and "”travel for shopping, personal or household care". Childcare includes the time devoted to "physical, medical childcare", "teach, help with homework", "read to, talk or play with child" and "supervise, accompany, other childcare". Time use activities are measured in hours per day. The analysis is restricted to working days, defined as days where respondents devote $60+$ minutes to market work activities excluding commuting, where market work is defined as the sum of the time devoted to the categories main7 "paid work, main job (not at home)", main8 "paid work at home", main9 "second or other job not at home", main11 "travel as a part of work" and main12 "other time at workplace". 
Figure 4. Mean time devoted to commuting, by mean time devoted to home production and childcare
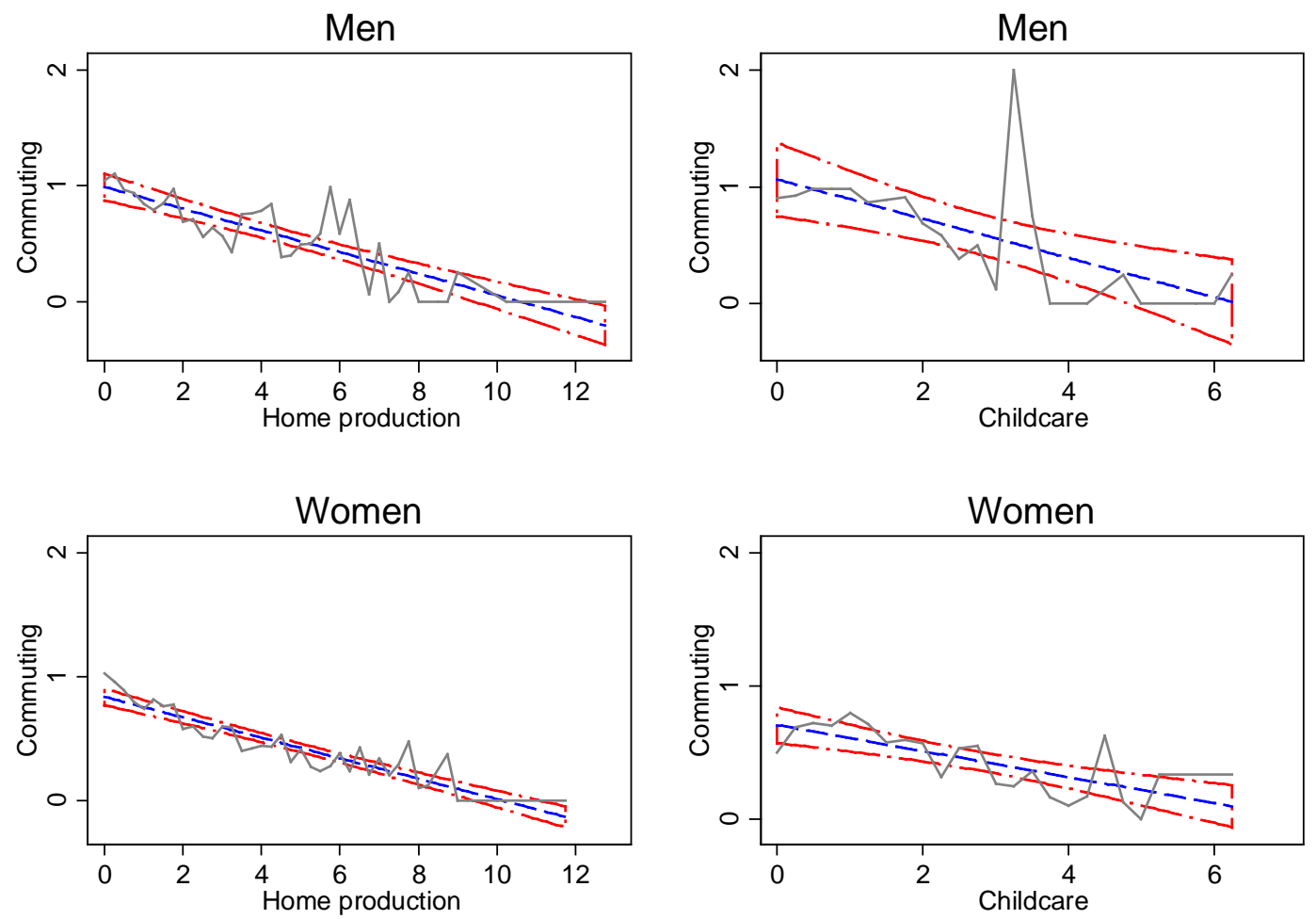

Notes: Sample consists of married male and female respondents aged 21-65, who are the head of the household or the spouse/partner of the household head, from the Dutch Time Use Survey, 2000 and 2005. Commuting is the time devoted to "travel to or from work". Home production includes the time devoted to "food preparation, cooking”, "set table, wash/put away dishes", "cleaning”, "laundry, ironing, clothing repair", "home/vehicle maintenance/improvement", "other domestic work", "purchase goods", "consume other services", "pet care (other than walk dog)", "adult care”, "child/adult care-related travel” and "”travel for shopping, personal or household care". Childcare includes the time devoted to "physical, medical childcare", "teach, help with homework", "read to, talk or play with child" and "supervise, accompany, other childcare". Time use activities are measured in hours per day. The analysis is restricted to working days, defined as days where respondents devote $60+$ minutes to market work activities excluding commuting, where market work is defined as the sum of the time devoted to the categories main7 "paid work, main job (not at home)", main8 "paid work at home", main9 "second or other job not at home”, main11 "travel as a part of work" and main12 "other time at workplace". 
Figure 5a. Distribution of the estimated propensity score for years 2000 and 2005, men

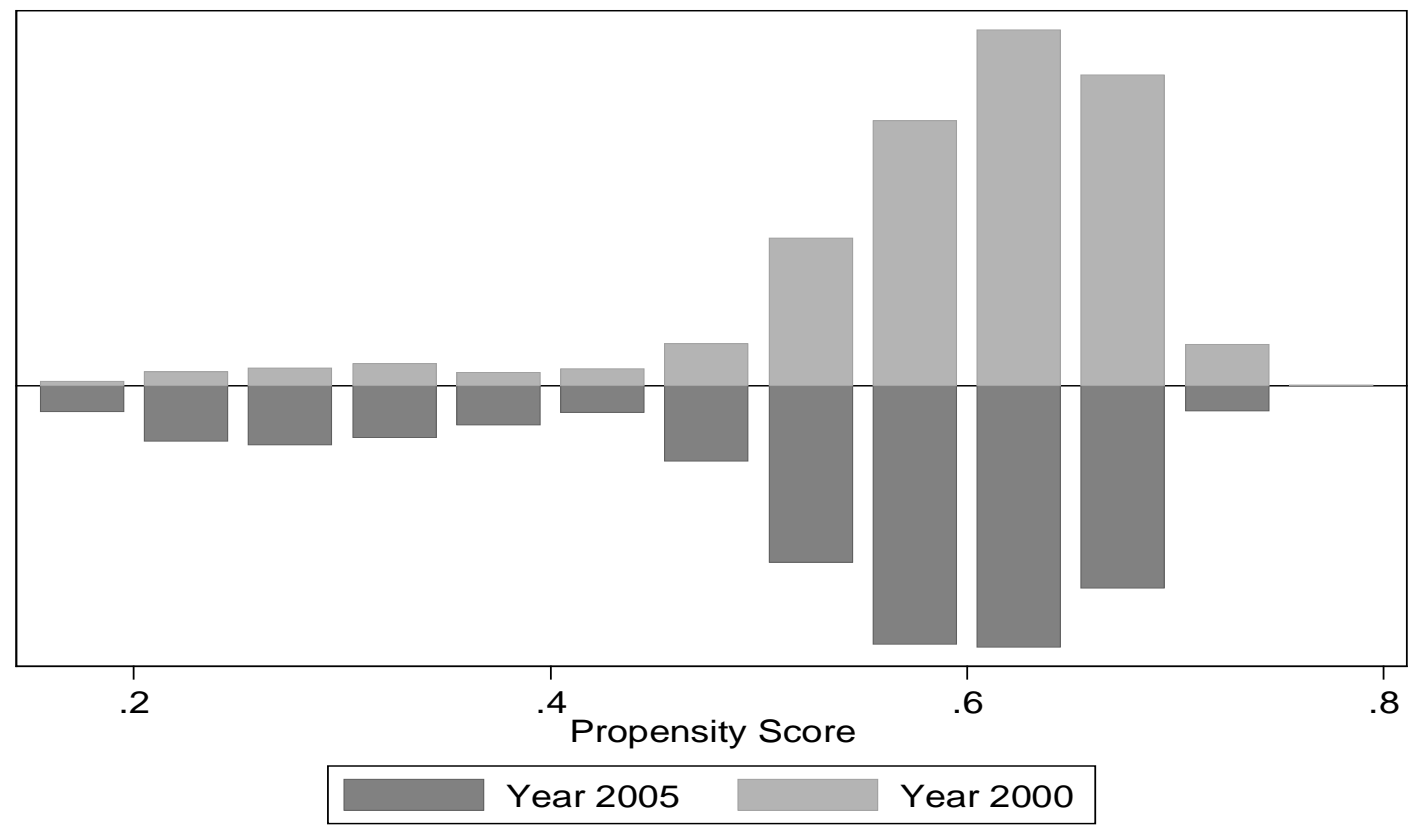

Notes: Sample consists of married male respondents aged 21-65, who are the head of the household or the spouse/partner of the household head, from the Dutch Time Use Survey, 2000 and 2005. Individuals in the year 2005 are considered the treated group, and individuals in the year 2000 are considered the untreated group.

Figure 5b. Distribution of the estimated propensity score for years 2000 and 2005, women

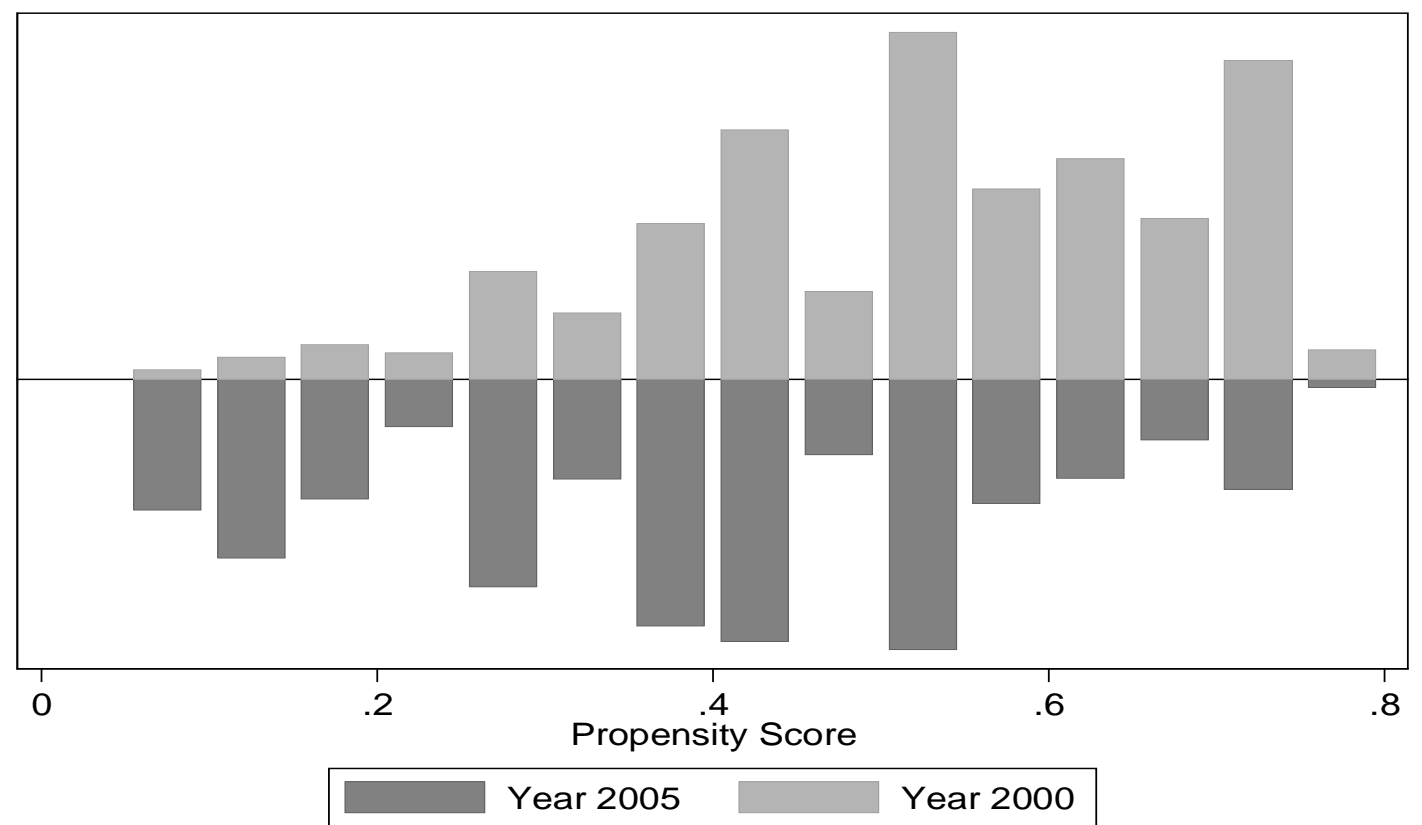

Notes: Sample consists of married female respondents aged 21-65, who are the head of the household or the spouse/partner of the household head, from the Dutch Time Use Survey, 2000 and 2005. Individuals in the year 2005 are considered the treated group, and individuals in the year 2000 are considered the untreated group. 
Table 1. Sum stats

\begin{tabular}{|c|c|c|c|c|c|c|}
\hline \multirow[b]{2}{*}{ Commuting } & \multicolumn{2}{|c|}{ Men } & \multicolumn{2}{|c|}{ Women } & \multirow{2}{*}{$\begin{array}{l}\text { Diff Men- } \\
\text { Women }\end{array}$} & \multirow{2}{*}{$\begin{array}{c}\text { p-value } \\
\text { diff }\end{array}$} \\
\hline & Mean & $\underline{\mathrm{SD}}$ & Mean & $\underline{\text { SD }}$ & & \\
\hline Time & $\overline{0.90}$ & $(\overline{0.02})$ & $\overline{0.62}$ & $(\overline{0.02})$ & 0.28 & $(0.00)$ \\
\hline Participation & 76.29 & $(0.88)$ & 70.62 & (1.10) & 5.67 & $(0.00)$ \\
\hline \multicolumn{7}{|l|}{$\underline{\text { Home production }}$} \\
\hline Time & 1.18 & $(0.03)$ & 2.65 & $(0.05)$ & -1.47 & $(0.00)$ \\
\hline Participation & 78.04 & $(0.85)$ & 95.47 & $(0.50)$ & -17.43 & $(0.00)$ \\
\hline \multicolumn{7}{|l|}{ Childcare } \\
\hline Time & 0.53 & $(0.02)$ & 1.06 & $(0.04)$ & -0.53 & $(0.00)$ \\
\hline Participation & 51.30 & $(1.40)$ & 67.59 & $(1.64)$ & -16.29 & $(0.00)$ \\
\hline \multicolumn{7}{|l|}{ Demographics } \\
\hline Age & 42.84 & $(0.42)$ & 40.87 & $(0.44)$ & 1.98 & $(0.00)$ \\
\hline Secondary education & 0.35 & $(0.02)$ & 0.51 & $(0.02)$ & -0.16 & $(0.00)$ \\
\hline University education & 0.46 & $(0.02)$ & 0.33 & $(0.02)$ & 0.14 & $(0.00)$ \\
\hline Working full-time & 0.90 & $(0.01)$ & 0.24 & $(0.02)$ & 0.66 & $(0.00)$ \\
\hline Partner employed & 0.67 & $(0.02)$ & 0.91 & $(0.01)$ & -0.24 & $(0.00)$ \\
\hline Number of children $<18$ & 1.05 & $(0.05)$ & 0.96 & $(0.05)$ & 0.10 & $(0.16)$ \\
\hline Youngest child $<5$ & 0.23 & $(0.02)$ & 0.24 & $(0.02)$ & -0.01 & $(0.77)$ \\
\hline Youngest child 5-12 & 0.22 & $(0.02)$ & 0.19 & $(0.02)$ & 0.03 & $(0.16)$ \\
\hline Youngest child 13-17 & 0.07 & $(0.01)$ & 0.09 & $(0.01)$ & -0.02 & $(0.35)$ \\
\hline At least one motorized vehicle at home & 0.95 & $(0.01)$ & 0.93 & $(0.01)$ & 0.02 & $(0.11)$ \\
\hline At least one computer at home & 0.91 & $(0.01)$ & 0.89 & $(0.01)$ & 0.02 & $(0.20)$ \\
\hline Household Income & 30.43 & $(0.86)$ & 29.65 & $(1.60)$ & 0.78 & $(0.67)$ \\
\hline Public sector & 0.14 & $(0.02)$ & 0.14 & $(0.02)$ & 0.00 & $(0.96)$ \\
\hline Living in urban area & 0.81 & $(0.02)$ & 0.80 & $(0.02)$ & 0.01 & $(0.62)$ \\
\hline Population density & 830.06 & $(41.12)$ & 750.22 & $(34.25)$ & 79.84 & $(0.14)$ \\
\hline Housing prices & 1.97 & $(0.02)$ & 1.87 & $(0.02)$ & 0.10 & $(0.00)$ \\
\hline Amsterdam, Rotterdam and the Hague & 0.05 & $(0.01)$ & 0.04 & $(0.01)$ & 0.02 & $(0.19)$ \\
\hline Drenthe & 0.05 & $(0.01)$ & 0.06 & $(0.01)$ & -0.01 & $(0.46)$ \\
\hline Flevoland & 0.03 & $(0.01)$ & 0.03 & $(0.01)$ & 0.00 & $(0.90)$ \\
\hline Friesland & 0.04 & $(0.01)$ & 0.06 & $(0.01)$ & -0.02 & $(0.13)$ \\
\hline Gelderland en Zop & 0.07 & $(0.01)$ & 0.10 & $(0.01)$ & -0.03 & $(0.09)$ \\
\hline Groningen & 0.05 & $(0.01)$ & 0.05 & $(0.01)$ & 0.00 & $(0.74)$ \\
\hline Limburg & 0.04 & $(0.01)$ & 0.04 & $(0.01)$ & 0.01 & $(0.57)$ \\
\hline Noord Brabant & 0.16 & $(0.02)$ & 0.15 & $(0.02)$ & 0.01 & $(0.76)$ \\
\hline Noord Holland & 0.11 & $(0.01)$ & 0.10 & $(0.01)$ & 0.01 & $(0.59)$ \\
\hline Overijssel en Nop & 0.10 & $(0.01)$ & 0.10 & $(0.01)$ & 0.00 & $(0.80)$ \\
\hline Utrecht & 0.08 & $(0.01)$ & 0.06 & $(0.01)$ & 0.02 & $(0.20)$ \\
\hline Zeeland & 0.03 & $(0.01)$ & 0.02 & $(0.01)$ & 0.01 & $(0.15)$ \\
\hline
\end{tabular}

Notes: Sample consists of married male and female respondents aged 21-65, who are the head of the household or the spouse/partner of the household head, from the Dutch Time Use Survey, 2000 and 2005. Commuting is the time devoted to "travel to or from work" and is measured in hours per day. The analysis is restricted to working days, defined as days where respondents devote $60+$ minutes to market work activities excluding commuting, where market work is defined as the sum of the time devoted to the categories main7 "paid work, main job (not at home)", main8 "paid work at home", main9 "second or other job not at home", main11 "travel as a part of work" and main12 "other time at workplace". Diff. Men-Women measures the difference in the overall value of the variable for men and women, $p$-value diff shows the p-value of a t-type test of equality of means. 
Table 2. Propensity score coefficients estimates

\begin{tabular}{|c|c|c|}
\hline \multirow[b]{2}{*}{ Propensity score estimates } & (1) & (2) \\
\hline & Men & Women \\
\hline Living in urban area & $\begin{array}{c}0.269 * * * \\
(0.045)\end{array}$ & $\begin{array}{c}0.345^{* * *} \\
(0.044)\end{array}$ \\
\hline Education & $\begin{array}{c}0.082 * * * \\
(0.024)\end{array}$ & $\begin{array}{c}0.298 * * * \\
(0.025)\end{array}$ \\
\hline Personal care & $\begin{array}{c}0.036 * * * \\
(0.010)\end{array}$ & $\begin{array}{c}0.0234 * * * \\
(0.009)\end{array}$ \\
\hline Market work & $\begin{array}{c}0.034^{* * *} \\
(0.009)\end{array}$ & $\begin{array}{c}0.034^{* * *} \\
(0.009)\end{array}$ \\
\hline At least one computer at home & $\begin{array}{c}0.750 * * * \\
(0.058)\end{array}$ & $\begin{array}{c}0.976 * * * \\
(0.051)\end{array}$ \\
\hline Working day & $\begin{array}{l}-0.029 \\
(0.079)\end{array}$ & $\begin{array}{c}0.289 * * * \\
(0.065)\end{array}$ \\
\hline Constant & $\begin{array}{c}-1.443^{* * *} \\
(0.140)\end{array}$ & $\begin{array}{c}-2.429 * * * \\
(0.129)\end{array}$ \\
\hline Observations & 5,513 & 6,516 \\
\hline Pseudo R-squared & 0.044 & 0.117 \\
\hline \multicolumn{3}{|c|}{$\begin{array}{l}\text { Notes: Sample consists of married male and female respondents aged } 21 \\
65 \text {, who are the head of the household or the spouse/partner of th } \\
\text { household head, from the Dutch Time Use Survey, } 2000 \text { and } 2005 \\
\text { Personal care and market work are measured in hours per day } \\
* \text { Significant at the } 90 \% \text { level **Significant at the } 95 \% \text { leve } \\
* * * \text { Significant at the } 99 \% \text { level. }\end{array}$} \\
\hline
\end{tabular}


Table 3. Results for market work and commuting

\begin{tabular}{|c|c|c|c|c|c|c|c|c|}
\hline \multirow[b]{3}{*}{ Commuting Time } & (1) & $(2)$ & (3) & (4) & (5) & (6) & (7) & (8) \\
\hline & \multicolumn{4}{|c|}{ Tobit models with original time } & \multicolumn{4}{|c|}{ Tobit models with imputed time } \\
\hline & Men & Women & Men & Women & Men & Women & Men & Women \\
\hline Home Production & $\begin{array}{c}-0.264 * * * \\
(0.022)\end{array}$ & $\begin{array}{c}-0.266 * * * \\
(0.019)\end{array}$ & $\begin{array}{l}- \\
-\end{array}$ & $\begin{array}{l}- \\
-\end{array}$ & $\begin{array}{c}-0.061 * * * \\
(0.014)\end{array}$ & $\begin{array}{c}-0.162 * * * \\
(0.013)\end{array}$ & $\begin{array}{l}- \\
-\end{array}$ & $\begin{array}{l}- \\
-\end{array}$ \\
\hline Childcare & $\begin{array}{l}- \\
-\end{array}$ & $\begin{array}{l}- \\
-\end{array}$ & $\begin{array}{c}-0.352^{* * *} \\
(0.067)\end{array}$ & $\begin{array}{c}-0.371^{* * *} \\
(0.048)\end{array}$ & $\begin{array}{l}- \\
-\end{array}$ & $\begin{array}{l}- \\
-\end{array}$ & $\begin{array}{c}-0.005 \\
(0.041)\end{array}$ & $\begin{array}{c}-0.148^{* * *} \\
(0.032)\end{array}$ \\
\hline \multicolumn{9}{|l|}{ Demographic characteristics } \\
\hline$\overline{\text { Age }}$ & $\begin{array}{c}0.001 \\
(0.035)\end{array}$ & $\begin{array}{c}0.080 * * \\
(0.031)\end{array}$ & $\begin{array}{c}0.079 \\
(0.077)\end{array}$ & $\begin{array}{c}0.067 \\
(0.069)\end{array}$ & $\begin{array}{l}-0.020 \\
(0.037)\end{array}$ & $\begin{array}{c}0.082^{* * *} \\
(0.030)\end{array}$ & $\begin{array}{c}0.063 \\
(0.082)\end{array}$ & $\begin{array}{c}0.082 \\
(0.070)\end{array}$ \\
\hline Age Squared & $\begin{array}{c}-0.002 \\
(0.040)\end{array}$ & $\begin{array}{c}-0.109 * * * \\
(0.038)\end{array}$ & $\begin{array}{l}-0.103 \\
(0.089)\end{array}$ & $\begin{array}{c}-0.112 \\
(0.088)\end{array}$ & $\begin{array}{c}0.020 \\
(0.042)\end{array}$ & $\begin{array}{c}-0.118^{* * *} \\
(0.037)\end{array}$ & $\begin{array}{c}-0.082 \\
(0.093)\end{array}$ & $\begin{array}{l}-0.119 \\
(0.091)\end{array}$ \\
\hline Secondary education & $\begin{array}{l}-0.038 \\
(0.112)\end{array}$ & $\begin{array}{l}0.203^{*} \\
(0.116)\end{array}$ & $\begin{array}{l}-0.014 \\
(0.164)\end{array}$ & $\begin{array}{c}0.103 \\
(0.173)\end{array}$ & $\begin{array}{l}-0.016 \\
(0.115)\end{array}$ & $\begin{array}{c}0.174 \\
(0.117)\end{array}$ & $\begin{array}{c}-0.031 \\
(0.166)\end{array}$ & $\begin{array}{c}0.089 \\
(0.178)\end{array}$ \\
\hline University education & $\begin{array}{c}0.118 \\
(0.116)\end{array}$ & $\begin{array}{l}0.225^{*} \\
(0.126)\end{array}$ & $\begin{array}{c}0.183 \\
(0.173)\end{array}$ & $\begin{array}{c}0.249 \\
(0.177)\end{array}$ & $\begin{array}{c}0.123 \\
(0.120)\end{array}$ & $\begin{array}{c}0.156 \\
(0.126)\end{array}$ & $\begin{array}{c}0.111 \\
(0.172)\end{array}$ & $\begin{array}{c}0.221 \\
(0.186)\end{array}$ \\
\hline Working full-time & $\begin{array}{c}0.480 * * * \\
(0.138)\end{array}$ & $\begin{array}{c}0.367 * * * \\
(0.105)\end{array}$ & $\begin{array}{c}0.731 * * * \\
(0.225)\end{array}$ & $\begin{array}{c}0.531 * * * \\
(0.175)\end{array}$ & $\begin{array}{c}0.727 * * * \\
(0.150)\end{array}$ & $\begin{array}{c}0.596 * * * \\
(0.112)\end{array}$ & $\begin{array}{c}0.906 * * * \\
(0.229)\end{array}$ & $\begin{array}{c}0.566 * * * \\
(0.175)\end{array}$ \\
\hline Partner employed & $\begin{array}{c}0.129 \\
(0.094)\end{array}$ & $\begin{array}{l}-0.207 \\
(0.149)\end{array}$ & $\begin{array}{c}0.110 \\
(0.129)\end{array}$ & $\begin{array}{c}0.264 \\
(0.352)\end{array}$ & $\begin{array}{c}0.073 \\
(0.097)\end{array}$ & $\begin{array}{c}-0.300 * * \\
(0.144)\end{array}$ & $\begin{array}{c}0.084 \\
(0.128)\end{array}$ & $\begin{array}{c}0.393 \\
(0.380)\end{array}$ \\
\hline Number of children $<18$ & $\begin{array}{c}-0.155 * * \\
(0.063)\end{array}$ & $\begin{array}{c}0.096 \\
(0.067)\end{array}$ & $\begin{array}{c}-0.200 * * * \\
(0.074)\end{array}$ & $\begin{array}{l}-0.089 \\
(0.080)\end{array}$ & $\begin{array}{c}-0.208 * * * \\
(0.069)\end{array}$ & $\begin{array}{c}-0.071 \\
(0.070)\end{array}$ & $\begin{array}{c}-0.238 * * * \\
(0.075)\end{array}$ & $\begin{array}{l}-0.106 \\
(0.082)\end{array}$ \\
\hline Youngest child $<5$ & $\begin{array}{c}0.478 * * * \\
(0.167)\end{array}$ & $\begin{array}{l}-0.285 * \\
(0.158)\end{array}$ & $\begin{array}{c}0.634^{* *} \\
(0.258)\end{array}$ & $\begin{array}{c}0.261 \\
(0.210)\end{array}$ & $\begin{array}{c}0.569 * * * \\
(0.178)\end{array}$ & $\begin{array}{l}-0.069 \\
(0.169)\end{array}$ & $\begin{array}{c}0.358 \\
(0.243)\end{array}$ & $\begin{array}{l}-0.338 \\
(0.217)\end{array}$ \\
\hline Youngest child 5-12 & $\begin{array}{l}0.409 * * \\
(0.172)\end{array}$ & $\begin{array}{c}0.110 \\
(0.164)\end{array}$ & $\begin{array}{l}0.345^{*} \\
(0.197)\end{array}$ & $\begin{array}{c}0.115 \\
(0.174)\end{array}$ & $\begin{array}{c}0.487 * * * \\
(0.181)\end{array}$ & $\begin{array}{c}0.171 \\
(0.170)\end{array}$ & $\begin{array}{c}0.287 \\
(0.193)\end{array}$ & $\begin{array}{l}-0.092 \\
(0.183)\end{array}$ \\
\hline Youngest child 13-17 & $\begin{array}{c}0.084 \\
(0.180)\end{array}$ & $\begin{array}{c}0.053 \\
(0.164)\end{array}$ & - & $\begin{array}{l}- \\
-\end{array}$ & $\begin{array}{c}0.160 \\
(0.185)\end{array}$ & $\begin{array}{c}0.186 \\
(0.162)\end{array}$ & $\begin{array}{l}- \\
-\end{array}$ & - \\
\hline At least one motorized vehicle at home & $\begin{array}{l}-0.001 \\
(0.173)\end{array}$ & $\begin{array}{c}0.187 \\
(0.145)\end{array}$ & $\begin{array}{c}0.194 \\
(0.333)\end{array}$ & $\begin{array}{c}0.097 \\
(0.228)\end{array}$ & $\begin{array}{c}-0.004 \\
(0.190)\end{array}$ & $\begin{array}{c}0.232 \\
(0.158)\end{array}$ & $\begin{array}{c}0.223 \\
(0.358)\end{array}$ & $\begin{array}{c}0.224 \\
(0.232)\end{array}$ \\
\hline At least one computer at home & $\begin{array}{c}0.105 \\
(0.151)\end{array}$ & $\begin{array}{l}-0.001 \\
(0.128)\end{array}$ & $\begin{array}{c}0.066 \\
(0.221)\end{array}$ & $\begin{array}{c}0.066 \\
(0.204)\end{array}$ & $\begin{array}{c}0.063 \\
(0.156)\end{array}$ & $\begin{array}{l}-0.114 \\
(0.133)\end{array}$ & $\begin{array}{c}0.001 \\
(0.232)\end{array}$ & $\begin{array}{c}0.011 \\
(0.208)\end{array}$ \\
\hline Household Income & $\begin{array}{l}-0.001 \\
(0.002)\end{array}$ & $\begin{array}{l}0.002 * \\
(0.001)\end{array}$ & $\begin{array}{c}0.003 \\
(0.003)\end{array}$ & $\begin{array}{c}0.004 * * * \\
(0.001)\end{array}$ & $\begin{array}{c}0.002 \\
(0.002)\end{array}$ & $\begin{array}{c}0.002 \\
(0.001)\end{array}$ & $\begin{array}{c}0.003 \\
(0.003)\end{array}$ & $\begin{array}{c}0.003^{* * *} \\
(0.001)\end{array}$ \\
\hline Public sector & $\begin{array}{l}-0.012 \\
(0.099)\end{array}$ & $\begin{array}{c}0.004 \\
(0.103)\end{array}$ & $\begin{array}{l}-0.217 \\
(0.144)\end{array}$ & $\begin{array}{c}0.062 \\
(0.137)\end{array}$ & $\begin{array}{l}-0.036 \\
(0.104)\end{array}$ & $\begin{array}{c}0.096 \\
(0.101)\end{array}$ & $\begin{array}{l}-0.231 \\
(0.146)\end{array}$ & $\begin{array}{c}0.091 \\
(0.140)\end{array}$ \\
\hline Living in urban area & $\begin{array}{c}0.069 \\
(0.099)\end{array}$ & $\begin{array}{c}0.056 \\
(0.089)\end{array}$ & $\begin{array}{l}-0.042 \\
(0.129)\end{array}$ & $\begin{array}{c}0.102 \\
(0.134)\end{array}$ & $\begin{array}{c}0.011 \\
(0.103)\end{array}$ & $\begin{array}{l}-0.044 \\
(0.095)\end{array}$ & $\begin{array}{l}-0.055 \\
(0.129)\end{array}$ & $\begin{array}{c}0.070 \\
(0.136)\end{array}$ \\
\hline Population density & $\begin{array}{c}0.007 \\
(0.006)\end{array}$ & $\begin{array}{c}-0.002 \\
(0.006)\end{array}$ & $\begin{array}{c}0.013 \\
(0.008)\end{array}$ & $\begin{array}{c}0.000 \\
(0.008)\end{array}$ & $\begin{array}{c}0.010 \\
(0.006)\end{array}$ & $\begin{array}{c}-0.001 \\
(0.006)\end{array}$ & $\begin{array}{l}0.015^{*} \\
(0.009)\end{array}$ & $\begin{array}{c}-0.002 \\
(0.009)\end{array}$ \\
\hline Housing prices & $\begin{array}{l}-0.609 * \\
(0.325)\end{array}$ & $\begin{array}{c}0.702^{* * * *} \\
(0.250)\end{array}$ & $\begin{array}{l}-0.501 \\
(0.460)\end{array}$ & $\begin{array}{c}0.798^{* *} \\
(0.381)\end{array}$ & $\begin{array}{l}-0.591^{*} \\
(0.335)\end{array}$ & $\begin{array}{c}0.753 * * * \\
(0.260)\end{array}$ & $\begin{array}{c}-0.662 \\
(0.471)\end{array}$ & $\begin{array}{c}0.981^{* *} \\
(0.395)\end{array}$ \\
\hline Amsterdam, Rotterdam and the Hague & $\begin{array}{l}-24.286 \\
(19.545)\end{array}$ & $\begin{array}{c}4.701 \\
(18.181)\end{array}$ & $\begin{array}{l}-41.118 \\
(27.387)\end{array}$ & $\begin{array}{c}-0.036 \\
(27.261)\end{array}$ & $\begin{array}{l}-31.845 \\
(20.209)\end{array}$ & $\begin{array}{c}2.546 \\
(18.052)\end{array}$ & $\begin{array}{l}-48.385^{*} \\
(28.103)\end{array}$ & $\begin{array}{c}4.726 \\
(28.562)\end{array}$ \\
\hline Drenthe & $\begin{array}{c}7.285 \\
(6.114)\end{array}$ & $\begin{array}{l}-1.362 \\
(5.699)\end{array}$ & $\begin{array}{l}12.412 \\
(8.553)\end{array}$ & $\begin{array}{c}0.300 \\
(8.566)\end{array}$ & $\begin{array}{c}9.645 \\
(6.327)\end{array}$ & $\begin{array}{l}-0.716 \\
(5.663)\end{array}$ & $\begin{array}{l}14.751^{*} \\
(8.785)\end{array}$ & $\begin{array}{l}-1.152 \\
(8.963)\end{array}$ \\
\hline Flevoland & $\begin{array}{c}6.834 \\
(5.719)\end{array}$ & $\begin{array}{l}-1.457 \\
(5.329)\end{array}$ & $\begin{array}{l}11.350 \\
(8.028)\end{array}$ & $\begin{array}{c}0.232 \\
(7.983)\end{array}$ & $\begin{array}{c}9.025 \\
(5.908)\end{array}$ & $\begin{array}{l}-0.776 \\
(5.296)\end{array}$ & $\begin{array}{l}13.472 \\
(8.227)\end{array}$ & $\begin{array}{l}-1.187 \\
(8.318)\end{array}$ \\
\hline Friesland & $\begin{array}{c}7.073 \\
(5.998)\end{array}$ & $\begin{array}{l}-1.150 \\
(5.612)\end{array}$ & $\begin{array}{l}12.247 \\
(8.420)\end{array}$ & $\begin{array}{c}0.197 \\
(8.415)\end{array}$ & $\begin{array}{c}9.593 \\
(6.210)\end{array}$ & $\begin{array}{l}-0.465 \\
(5.572)\end{array}$ & $\begin{array}{l}14.512 * \\
(8.644)\end{array}$ & $\begin{array}{l}-1.324 \\
(8.808)\end{array}$ \\
\hline Gelderland en Zop & $\begin{array}{c}6.172 \\
(4.964)\end{array}$ & $\begin{array}{l}-1.141 \\
(4.599)\end{array}$ & $\begin{array}{c}9.882 \\
(6.966)\end{array}$ & $\begin{array}{c}0.308 \\
(6.917)\end{array}$ & $\begin{array}{c}8.086 \\
(5.135)\end{array}$ & $\begin{array}{c}-0.622 \\
(4.566)\end{array}$ & $\begin{array}{l}11.776 * \\
(7.149)\end{array}$ & $\begin{array}{l}-1.002 \\
(7.235)\end{array}$ \\
\hline Groningen & $\begin{array}{c}6.860 \\
(5.651)\end{array}$ & $\begin{array}{l}-0.941 \\
(5.277)\end{array}$ & $\begin{array}{l}11.377 \\
(7.924)\end{array}$ & $\begin{array}{c}0.743 \\
(7.949)\end{array}$ & $\begin{array}{c}9.162 \\
(5.854)\end{array}$ & $\begin{array}{c}-0.301 \\
(5.246)\end{array}$ & $\begin{array}{l}13.384 * \\
(8.129)\end{array}$ & $\begin{array}{l}-0.761 \\
(8.308)\end{array}$ \\
\hline Limburg & $\begin{array}{c}4.842 \\
(4.035)\end{array}$ & $\begin{array}{l}-0.726 \\
(3.787)\end{array}$ & $\begin{array}{c}8.374 \\
(5.701)\end{array}$ & $\begin{array}{l}-0.287 \\
(5.679)\end{array}$ & $\begin{array}{c}6.453 \\
(4.180)\end{array}$ & $\begin{array}{l}-0.490 \\
(3.772)\end{array}$ & $\begin{array}{l}9.880^{*} \\
(5.850)\end{array}$ & $\begin{array}{l}-1.279 \\
(5.938)\end{array}$ \\
\hline Noord Brabant & $\begin{array}{c}5.486 \\
(4.410)\end{array}$ & $\begin{array}{l}-1.326 \\
(4.083)\end{array}$ & $\begin{array}{c}8.870 \\
(6.187)\end{array}$ & $\begin{array}{c}-0.194 \\
(6.148)\end{array}$ & $\begin{array}{c}7.183 \\
(4.563)\end{array}$ & $\begin{array}{c}-0.831 \\
(4.061)\end{array}$ & $\begin{array}{c}10.576 * \\
(6.354)\end{array}$ & $\begin{array}{l}-1.354 \\
(6.431)\end{array}$ \\
\hline Noord Holland & $\begin{array}{c}1.933 \\
(1.553)\end{array}$ & $\begin{array}{c}-0.352 \\
(1.430)\end{array}$ & $\begin{array}{c}2.793 \\
(2.182)\end{array}$ & $\begin{array}{c}0.122 \\
(2.145)\end{array}$ & $\begin{array}{c}2.473 \\
(1.607)\end{array}$ & $\begin{array}{c}-0.196 \\
(1.422)\end{array}$ & $\begin{array}{c}3.397 \\
(2.236)\end{array}$ & $\begin{array}{l}-0.350 \\
(2.235)\end{array}$ \\
\hline Overijssel en Nop & $\begin{array}{c}6.314 \\
(5.233)\end{array}$ & $\begin{array}{l}-1.152 \\
(4.875)\end{array}$ & $\begin{array}{l}10.940 \\
(7.351)\end{array}$ & $\begin{array}{c}0.234 \\
(7.314)\end{array}$ & $\begin{array}{c}8.343 \\
(5.420)\end{array}$ & $\begin{array}{c}-0.560 \\
(4.843)\end{array}$ & $\begin{array}{l}12.892 * \\
(7.543)\end{array}$ & $\begin{array}{l}-0.971 \\
(7.653)\end{array}$ \\
\hline Utrecht & $\begin{array}{c}3.236 \\
(2.374)\end{array}$ & $\begin{array}{l}-0.773 \\
(2.193)\end{array}$ & $\begin{array}{c}5.085 \\
(3.322)\end{array}$ & $\begin{array}{l}-0.027 \\
(3.313)\end{array}$ & $\begin{array}{l}4.101^{*} \\
(2.446)\end{array}$ & $\begin{array}{c}-0.544 \\
(2.173)\end{array}$ & $\begin{array}{l}6.040^{*} \\
(3.405)\end{array}$ & $\begin{array}{c}-0.754 \\
(3.471)\end{array}$ \\
\hline Zeeland & 7.023 & -1.386 & 11.522 & -0.065 & 9.303 & -0.976 & 13.755 & -1.663 \\
\hline
\end{tabular}




\begin{tabular}{lcccc|cccc} 
& $(5.936)$ & $(5.532)$ & $(8.366)$ & $(8.367)$ & $(6.154)$ & $(5.480)$ & $(8.581)$ & $(8.750)$ \\
Constant & -9.860 & -2.407 & $-18.083^{*}$ & -4.696 & $-12.718^{*}$ & -3.153 & $-20.398^{* *}$ & -3.877 \\
& $(6.875)$ & $(6.447)$ & $(10.021)$ & $(9.697)$ & $(7.114)$ & $(6.412)$ & $(10.298)$ & $(10.185)$ \\
Observations & & & & & & & \\
Pseudo R-squared & 3,571 & 4,020 & 1,889 & 2,045 & 3,571 & 4,020 & 1,889 & 2,045 \\
\hline & 0.190 & 0.228 & 0.163 & 0.155 & 0.153 & 0.184 & 0.149 & 0.126 \\
\hline
\end{tabular}

Notes: Sample consists of married male and female respondents aged 21-65 in working days, who are the head of the household or the spouse/partner of the household head, from the Dutch Time Use Survey, 2000 and 2005. Commuting is the time devoted to "travel to or from work". Home production includes the time devoted to "food preparation, cooking”, "set table, wash/put away dishes", "cleaning”, "laundry, ironing, clothing repair", "home/vehicle maintenance/improvement”, "other domestic work", "purchase goods”, "consume other services”, "pet care (other than walk dog)", "adult care", "child/adult care-related travel" and "”travel for shopping, personal or household care". Childcare includes the time devoted to "physical, medical childcare”, "teach, help with homework", "read to, talk or play with child" and "supervise, accompany, other childcare". Time use activities are measured in hours per day. The analysis for the relationship between commuting and childcare is restricted to individuals with at least one child under 18 in the household. *Significant at the 90\% level **Significant at the $95 \%$ level ***Significant at the $99 \%$ level. 